\title{
FACTORS RELATED TO STUDENT RETENTION IN COMMUNITY \\ COLLEGE DEVELOPMENTAL EDUCATION MATHEMATICS
}

\author{
DISSERTATION
}

\author{
Presented to the Graduate Council of the \\ University of North Texas in Partial \\ Fulfillment of the Requirements
}

For the Degree of

DOCTOR OF PHILOSOPHY

By

\author{
Udoudo J. Umoh, B.S., M.S. \\ Denton, Texas \\ August, 1992
}




\title{
FACTORS RELATED TO STUDENT RETENTION IN COMMUNITY \\ COLLEGE DEVELOPMENTAL EDUCATION MATHEMATICS
}

\author{
DISSERTATION
}

\author{
Presented to the Graduate Council of the \\ University of North Texas in Partial \\ Fulfillment of the Requirements
}

For the Degree of

DOCTOR OF PHILOSOPHY

By

\author{
Udoudo J. Umoh, B.S., M.S. \\ Denton, Texas \\ August, 1992
}




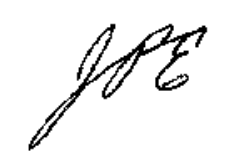

Umoh, Udoudo J., Factors Related To student Retention In Community College Developmental Ecucation Mathematics. Doctor of Philosophy (Higher Education), August, 1992, 143 pp., 12 tables, 3 illustrations, references, 124 titles. This study investigated the factors related to student retention in a comprehensive community college developmental education mathematics program. The purpose was to identify and describe these factors and to develop strategies for improving retention in the community college developmental education mathematics program. Tinto's 1975 model of institutional departure was employed to examine different factors relating to retention in developmental education mathematics courses.

In accordance with established criteria, data were collected using the Institutional Integration scale (IIS) and students Existing Records (SER). The IIS survey instrument questionnaire was completed by 41 students from a sample of 56 developmental education students enrolied in college level mathematics, and the data thus collected were used for analysis. 
Data were analyzed using frequency count, percentage, and the chi-square statistical analysis with a significant level of 0.05 . The analysis of the data showed that the responding sample was primarily white, females aged 18 to 45. Most of the respondents had high grade point averages, dio not miss any developmental education mathematics classes, and attended extra curricular activities infrequently. More fathers than mothers of the sample population had receivea a college education. Academic goal comitment, institutional experience, academic involvement, and placement grades were not statistically significant factors influencing retention.

Among the major findings were: Development education instructors appearea to make the aifference, institutional experience, academic goal commitment, and placement grades did not appear to play a major role; the students' academic involvement beyond classes appeared negligible; age, gender, grade point average, and parental educational levels were not significant factors for student retention in developmental education mathematics courses. Although statistical evidence did not support reversal of the proposed null hypotheses, pertinent issues for further research were raised. 


\section{ACKNOWLEDGMENTS}

There were many individuals whose inspiration, interest, ideas, support, and efforts eased the completion of this study. The greatest inspiration came from my wife Abigail and from my professors. I extend special appreciation to my committee: Dr. John Eddy (Major Professor) whose fatherly advice, professional guidance, motivation, and encouragement had the greatest impact on the study's development and completion; Dr. Tom Richards (Minor Professor) who was always there when I needed him for his expert advice in statistics and related areas will never be forgotten, Dr. William A. Miller (Committee member and Department Chair) constantly and consistently gave fatherly advice throughout the entire process, and Dr. John E. Allen (Committee Member) advised and counseled me along the way whenever I needed help from him.

To my wife, Abigail, and my daughters, Idotenyin (Hope) and Faith, I extend my love and heartfelt appreciation for their unlimited support, understanding, patience, encouragement, guidance, and motivation.

To my senior brother, Okon, and my last brother Etim, I extend my eternal gratitude for their support and positive direction throughout my educational career. 
To Aniefiok Udo and Uduak Affia I extend my heartfelt appreciation for their support, encouragement, and prayers during the final phase of this study. I gratefuliy acknowledge all my other friends and colleagues for their assistance and encouragement as well as for their moral and prayerful support.

To Juanita Astin, Dean of Developmental Education for Collin County Community College, I extend my deepest appreciation for her unwavering support and encouragement. Finally and ultimately, I give daily thanks to God Almighty--who is the author of wisdom, knowledge, and understanding--for leading me through all my studies to this, the brink of my life of service. 
TABLE OF CONTENTS

Page

ACKNOWLEDGMENTS . . . . . . . . . . . . . . . . . . i i

LIST OF TABLES • . . . . . . . . . . . . . . • . v vi

LIST OF ILLUSTRATIONS . • • • • . . . • . • . . . . . vii

Chapter

1. INTRODUCTION . . . . . . . . . . . . . . 8

statement of the Problem

8

Purposes of the study

Research Hypotheses

Significance of the study

Definition of Terms

Delimitation of the study

Limitation of the study

2. REVIEW OF RELATED LITERATURE . • • . . . . . . 24

Introduction

Historical Perspective

Conceptual Models of Student Attrition

Atheoretical Models: The Descriptive

Studies

Prematriculation Characteristics

Person-Role Fit

The Longitudinal-Process Models

Bean's Industrial Model of Student

Attrition

The Synthetic Model

Family Background and Institutional

Characteristics

Academic Success, Achievement, and Goal Commitment

Developmental Education

Developmental Mathematics Programs

3. METhOdS AND PROCEdURES . . . . . . . . . . 62

Introduction

Sample Population

Instrumentation

Procedures for Data Collection

Analysis and Treatment of Data 
4. PRESENTATION AND ANALYSIS OF DATA . . . . * . . 69 Introduction Research Hypotheses Description of Sample Summary

5. SUMMARY, CONCLUSTONS, AND RECOMMENDATIONS . . 89 Summary Findings and Discussion of Data Analysis Conclusions Recommendations for Further Research

APPENDICES

A. CORRESPONDENCE . . . . . . . . . . . . . 101

B. SIUDENT INFORMATION QUESTIONNARIES . . . . . . 107

C. CHART 1... . . . . . . . . . . 116

D. Chi-SQuare CalCulations . . . . . . . . . . 119

E. Appendix E . . . . . . . . . . . . . . 128 REFERENCES . . . . . . . . . . . . . . . . . 133 


\section{LIST OF TABLES}

Table

Page

1. Factors that Affect Retention . . . . . . . 73

2. Academic Goal Commitment vs. Retention . . . . 77

3. Institutional Experience vs. Retention . . . . . 79

4. Student Academic Involvement vs. Retention . . . 82

5. Chi-square Calculations for Hypothesis l(a): . 120 Gender vs. Student Retention

6. Chi-square Calculations for Hypothesis 1(b): . . 121 Age vs. Student Retention

7. Chi-square Calculations for Hypothesis l(c): . . 122 Grade Point Average vs. Student Retention

8. Chi-square Calculations for Hypothesis 1(d): . 123 Parents' Education vs. Student Retention

9. Chi-square Calculations for Hypothesis 2: . . 124 Academic Goal Achievement vs. Student Retention

10. Chi-square Calculations for Hypothesis 3: . . 125 Institutional Experience vs. Student Retention

11. Chi-square Calculations for Hypothesis 4: . . 126 Student Academic Involvement VS. student Retention

12. Chi-square Calculations for Hypothesis 5: . . 127 Grades vs. Student Retention 


\section{LIST OF ILLUSTRATIONS}

Figure $\quad$ Page

1. A conceptual model of institutional departure . . 13

2. Impact/typology of goal commitment upon . . . . . 43 student retention/success

3. Chart 1: Research hypotheses . . . . . . . 117 
CHAPTER 1

INTRODUCTION

The student withdrawal rate from colleges in the united States has long been recognized as a significant social, economic, and educational problem. Despite efforts to curb attrition by various colleges and universities through programs, experiments, and research, only 4 out of every 10 students who have enrolled in colleges and universities have graduated (Astin, 1978). Reasons that have contributed to the high aropout rate in the United states have remained largely unknown (Lenning, Beal, \& Sauer, $1980)$.

Many factors that determined if a student enrolled in college and where that student attended also influenced whether or not the student stayed to complete the course. In recent years, the problem ot retention, particularly in the areas of developmental education, has concerned most college administrators and faculties (Beal \& Noel, 1980).

As colleges and universities have experienced declines in enroliment, renewed attention has been given to students' persistence. Under current enrollment conditions, administrators can no longer take the casual 
attitude that if one student leaves another will be waiting to enrol1. Nowhere today has this renewed interest in student persistence been more prevalent than in community colleges (El-Khawas, 1986a).

El-Khawas (1986b) reported that $85 \%$ of the community colleges surveyed in 1985 had programs for monitoring student retention, compared to 64 in 1984. El-Khawas' report clearly indicated an interest among administrators in keeping students in school for cost-effective purposes. Even more important was the reportedly stronger commitment to retain students because it was in the interest of the students themselves (Astin, 1975, 1987; Astin, Korn, \& Green, 1987; Bean \& Metzner, 1985, 1987). Astin, Korn, and Green noted that in recent years student retention and student satisfaction with the college experience had become urgent, complex issues for campus officials.

While the campus environment was a factor that affected all students' decision to stay or drop out of school, the campus environment sometimes affected developmental education students more acutely. Studies showed that developmental education students who withdrew from college often rated the presence of a hostile racial climate as an important reason for their withdrawal. Observers reported that faculties, especially in senior colleges and research institutions, often had negative attitudes toward remedial 
students, and that these instructors were often poorly prepared to teach them (Gross, 1981).

A substantial presence on campus of representative group faculty members has been recommended as a fundamental step in improving campus environments. As early as the 1970s, the shortage of African American and Hispanic instructors at 2-year colleges was noted as a particular problem (Olivas, 1979). Some writers had predicted that work with low income or minority students may also have suffered if developmental programs were inadequately financed, superficial, lacked permanence or institutional support, and were viewed as outside the institution's central purpose (Peterson, 1978).

Earlier research on student retention had not been accepted without criticism. The failure to use theoretical models to explain the withdrawal process, the use of univariate or bivariate statistical procedures, and the uses of ex post facto research designs had been major criticisms of earlier student retention research (Lea, Sedlacek, \& Stewart, 1979; Lenning, Beale, \& Sauer, 1980; Pantages, \& Creedon, 1978; Tinto, 1975). Kohen, Nestel, and Karmas (1978) suggested that failure to view college students' success as a sequential process placed severe limitations on the usefulness of retention research. 
Spady (1971) incorporated selected concepts from Durkheim's theory of suicide to formulate the first theoretical model of the college dropout process. Durkhejm (1961) contended that there was a higher likelihood of suicide when an individual did not receive sufficient support from friends and peers, and when there was incongruence between the values of the group and those of the individual. Spady (1971) compared dropout behavior to suicide and reported that similar group value systems and peer support mechanisms influenced nonpersistent behavior in students.

In 1975 Tinto presented a model of student retention that was based on a review of literature. 'The model has been extensively testea and validated in a variety of institutional settings (Kasworm, 1980; Pascarella \& Chapman, 1983). Although the models of Spady (1971) and rinto (1975), as well as the student faculty model proposed by Pascarella (1980), showed the same theoretical basis of the social and academic integration of college students, their models were designed primarily to study retention of traditional stuojents at residential 4-year colleges and universities (Laman, 1989). Recently, however, Halpin (1990) and Attinasi (1986) used the l'into model at an open door nonresidential comprehensive community college. The results of many research studies in higher education indicated that retention was a complex issue that 
seldom had a single cause, but involved the interaction of different variables (Astin, 1975; Cope \& Hannah, 1975; Lenning et al., 1980; Tinto, 1975, 1987). Recognized variables included factors related to student characteristics and student institutional interaction, academic aptitude and performance, level of aspiration and motivation, institutional type, image, students' services offered, and student involvement; plus the development of a sense of belonging or degree of fit that results from student institution interaction (Beal \& Noel, 1980; Lenning et al., 1980). Retention, student satisfaction, and student success appeared to improve when retention efforts were geared toward integrating the student's total educational experience. Therefore, this study has examined the relationship between several variables that have been identified through retention research concerning 2-year developmental mathematics prograns. The conceptual model that fit this description was Tinto's model of institutional departure (see Figure 1 ).

Iinto's model consisted of background characteristics (including family background, inaividual skills and ability, and precollege schooling) that interacted with each other and that were expected to influence goal comitment (graduation) as well as institutional commitment (re-enrollment). In the academic system, goal commitment 


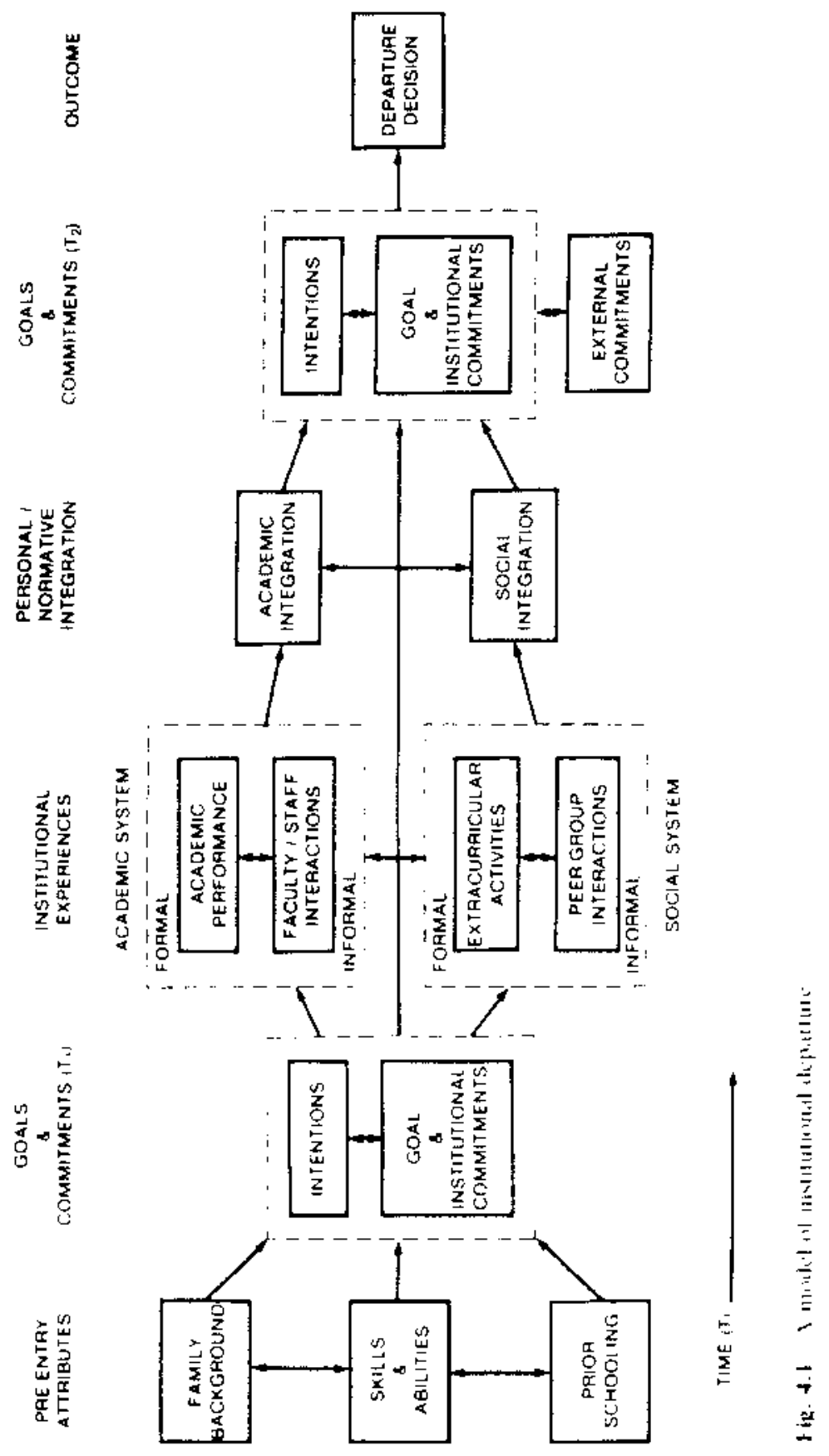

Figure 1. A model of institutional departure (Tinto, 1987) 
tended to lead to higher grade performance and intellectual development, which in turn led to academic integration. Academic integration led to even greater goal commitment, and goal commitment reduced the likelihood of students' dropping out. In the social system, institutional commitment was expected to produce peer group and faculty interaction, which led to social integration. In turn, social integration increased institutional commitment, and institutional commitment was also expected to reduce the likelihood of students' dropping out (Tinto, 1987).

Because Tinto placed goal commitment and institutional commitment twice in the conceptual model, the first type of goal commitment considered in this study was a product of prematriculation characteristics, and the second was the product of academic integration (Bean, 1982). This position was taken because at any particular point in a student's career the student would have a single notion or goal commitment that was expected to be the product of both prematriculation characteristics and academic/social integration, so that experience modified attitudes. The second goal commitment was expected to be the best predictor of dropout decisions. The initial goal commitment was considerea to be eaucational planning rather than commitment to carry out these plans. 
Statement of the Problem

The problem of this study concerned factors related to student retention in community college developmental education mathematics.

$$
\text { Purposes of the study }
$$

One purpose of the study was to identify and describe factors related to student retention in commity college developmental mathematics courses. A second purpose was to develop a strategy for improving student retention in community college developmental mathematics programs.

\section{Research Hypotheses}

Hypothesis 1

HI(a). There is no significant relationship between gender and student retention in developmental education mathematics.

HI(b). There is no significant relationship between age and student retention in developmental education mathematics.

$H I(c)$. There is no significant relationship between grade point average (GPA) and student retention in developmental education mathematics. 
H $1(d)$. There is no significant relationship between parents' education and student retention in developmental education mathematics.

\section{Hypothesis 2}

There is no significant relationship between academic goal commitment and student retention in developmental education mathematics.

Hypothesis 3

There is no significant relationship between institutional experience and student retention in developmental education mathematics.

\section{Hypothesis 4}

There is no significant relationship between student academic integration and student retention in developmental education mathematics.

Hypothesis $\underline{5}$

There is no significant relationship between placenent gracies, student performance, and student retention in college level mathematics.

$$
\text { Significance of the study }
$$

There were several reasons college and university administrators, faculty, concerned parents, and stuajents 
would want to discover why developmental education students were successful. Given the changing profile and declining enrollment patterns of students--both traditional and nontraditional--attending community colleges, it became imperative for college leadership to be aware of the cost of attrition, both to the students and to the institutions (Lenning et al., 1980). Miller and Roder (1983) believed that "detail and follow up procedures are vital to the entire operation."

In the 1980 view of Lenning et a1., students who dropped out wasted time, energy, and money; furthermore, the negative college experience might very well discourage them from trying again. From the college perspective, improving retention or reducing attrition was one way to combat declining enrollments and the accompanying decrease in funding that threatened many colleges and universities (Lenning et al, 1980). Thus, the knowleage of what influenced developmental education students to persist or withdraw was critical to effective educational program planning and to the development of successful retention/attrition strategies.

The proposed study was significant in that it helped institutions to appropriately prepare for and use their human and financial resources. This study could give institutions an appropriate understanding of why developmental education students left college, thus 
providing data that could enable them to identify ways of providing intervention strategies to improve developmental education goal accomplishment. In summary, the effectiveness of colleges in meeting ajevelopmental education students' needs could be improved if more were known about why developmental students withdraw. This study was also significant because of the choice of the community college in which the study was undertaken. According to official records and to interviews with Juanita Astin, Dean of Developmental Education (personal communication, 1 April 1991), and Gerald H. Perkus, Director of Institutional Research (personal communication, 11 February 1991), Collin county Community College (CCCC) was one of the fastest growing colleges in Texas and in the Nation. CCCC was located among one of the most highly educated populations in the state of Texas, but its highest dropout rate was in the area of developmental equcation in mathematics. If CCCC was having problems with student retention, what about retention in the rest of the colleges in the state, or in the Nation?

Definitions of Terms

Academic goals are primarily those goals stated on the National Center for Higher Education Management systems/ Student outcomes Information Services (SOIS) 
Questionnaire: (a) to increase knowledge and understanding in an academic field, (b) to obtain a degree or certificate, and (c) to complete a course necessary to transfer to another educational setting.

Academic integration is the interaction between students and the academic activities and systems of an institution. The level of academic integration is a function of grade performance, intellectual development, perception of faculty concern for quality teaching and student development, and informal contacts with faculty concerning academic, intellectual, and career matters (rinto, 1975$)$.

Autopsy is a critical examination, evaluation, or assessment (Pascarella \& Terenzini, 1983).

Comprehensive community college refers to a 2-year institution of higher education that provides curricular functions addressing academic transfer preparation, vocational technical education, continuing education, developmental education, and community service; an institution that is accredited to award the associate degrees in arts or sciences.

College services means services which are provided by colleges and designed to assist students. The services evaluated for this study are listed on the soIs Continuing-student and Former-student questionnaire (Lenning et al., 1980). 
Continuing students are students who have been successfully enrolled for 1 year (fall 1989 to spring 1990) at a comprehensive community college.

Developmental education refers to furthering students' skills, attitudes, and strengths as well as correcting their weaknesses in areas beyond the normal academic subject matter.

Educational goal refers to the level of degree (noncertificate, certificate, associate, bachelor, or graduate) that the student is currently pursuing.

Dropouts are students who leave an institution and do not return to complete a developmental education goal (Lenning et al., 1980).

Environmental factors are factors over which the institution has little control, factors that might cause a student to witharaw voluntarily (Tinto, 1975). These factors include ability to finance a college education, employment, the extent of outside encouragement to remain in college, the extent of family responsibilities, and the opportunity to transfer to another college (Bean, 1985; Tinto, 1975)

Goal commitment means the magnitude of importance a student gives to obtaining a college education. This commitment may be viewed either from a prematriculation or a postmatriculation perspective. 
High-risk students are students who are academically under-prepared, have low educational appreciation and poor stuay habits, or have parents who are relatively uneducated (Astin, 1975).

Institutional commitment refers to students' loyalty to a college regarding completion of their educational goals as determined by students' indication of whether or not attending a comprehensive college was their first choice (Bean, 1985; Tinto, 1975).

Nonpersisters are students who stay for only one semester of developmental studies.

Persistence is a characteristic exhibited by students who maintain a consistent enrollment pattern until an educational goal has been achieved. An educational goal represents the completion of developmental programs.

Persisters are students who continue enrollment at the same institution until their developmental education program goals are achieved.

Program completers are students who completed all of their developmental education course work from fall 1989 to summer 1991 .

Program noncompleters are students who did not complete all of their developmental courses and did not remain continuously enrolled from 1989 to 1991.

Retention refers to a student's remaining enrolled and being successful in achieving a mandated developmental 
education goal from initial developmental mathematics enrollment through appropriate college-level mathematics. Social and cultural participation goals are primarily those goals stated on the SoIs questionnaires: (a) to become actively involved in student life and campus activities, (b) to increase participation in cultural and social events, (c) to meet people, and (d) self-reported social and cultural goals.

Academic success refers to students' completion of their developmental mathematics course sequence.

\section{Delimitation of the study}

This study was limited to continuous (as well as noncontinuous or noncompleter) enrollees of developmental mathematics courses trom the fall of 1989 who were still taking courses at CCCC in the spring and/or summer semesters of 1991. This study was an in-depth survey analysis, cross-sectionial by design.

\section{Limitation of the study}

When interpreting correlations, it is essential to remember that a high correlation does not necessarily indicate that a causal relationship exists between two variables. The correlation might be due to a third or different variable (confounding). Therefore, care must be exercised in arawing conclusions; factors with a 
significant high correlation are considered relational but no causal relationship is inferred.

Generalization and interpretations of this study were subject to 1 imitations:

1. Because this study was limited to students at a comprehensive community college, it would be difficult to generalize beyond the population used in the study.

2. The study was restricted to developmental eaucation mathematics students enrolled during the spring and summer semesters of 1991 .

3. The study was limited to students at the CCCC aistrict in Plano, Texas.

4. Because the study was restricted by various limitations; therefore, all the possible reasons associated with developmental education mathematics program completers and noncompleters could not have been exhausted. 
CHAPTER 2

REVIEW OF RELATED LITERATURE

\section{Introduction}

Student retention has been a much-studied phenomenon (Tinto, 1987). There have been few problems in higher. education that have received as much attention (Cope \& Hannah, 1975; Iffert, 1957; McNeely, 1937; Pantages \& Creedon, 1978; Summerskill, 1962; Tinto, 1975). However, there is still much that is not known about the complex and multidimensional processes involved with retention, especially with developmental education in general and developmental mathematics in particular (Tinto, 1987).

The literature relevant to this study was grouped into six major topics: (a) historical perspective; (b) conceptual models of attrition; (c) family background and/or institutional characteristics; (d) academic success and/or achievement and goal commitment; (e) developmental education; and (f) developmental mathematics programs.

\section{Historical Perspective}

Historically, junior and community colleges were less concerned with student persistence than were senior 
institutions. This position was taken in part because of the increasing enrollment trends that community and junior colleges experienced during the 1960 s and early 1970 s. However, changing student demographics (including decreases in the 18 to 22-year-old population and increases in the adult student population), limited fiscal resources, and local and state expectations of accountability have resulted in the need to address student attrition seriously (Deegan, Tillery, \& Associates, 1985; Dressel \& Simpson, 1980; Vaughan, 1980). Pre-World War II studies on retention were largely descriptive. These early studies showed, among other things, that commuters, students with lower aptitudes, and students from small towns tended not to complete college. After world War II, the emphasis on retention research shifted to prediction. Researchers asked: Given commuting, scholastic test scores, and town size, what was the likelihood of students' completing their education (Beai \& Noel, 1980)? In the late 1950s, attention shifted to the fit between students and institutions. In the 1960s, attention shifted again to typologies of student dropouts and to the students' experiences while in attendance (Beal \& Noel, 1980).

It was not until the 1970s, that serious consideration was given to the institutions themselves (Cope, 1980). Furthermore, until a few years ago, the dominant assumption was that there was something wrong with students when a 
degree was not earned in the requisite time (4 years in the university and 2 years in the 2-year commity college). only recently has the research reported seriously on what institutions do to discourage completion. Many recent studies have reported on millions of men and women who did a lot of stopping out and transferring as they sought more satisfying environments--both collegiate and noncollegiate. The current trend in research was to focused more on the quality of faculty-student interaction, the type of degree programs available, the adequacy of student residences, the mix of financial aid, and other such factors related to retention (Beal \& Noel, 1980). Clearly, in order to retain the confidence of students, the emphasis had shifted to the improvement of the quality of higher education.

While the literature on student attrition was abundant, it had been very difficult to generalize the findings from one institution to another. This was due to differences in institutional (2-year vs. 4-year) as well as student characteristics (commuter vs. residential). Pascarella, Smart, and Ethington (1986) noted that patterns of influence on student persistence or withdrawal behavior may differ substantially for different institutions. For this reason, researchers have advocated that single-institution research was necessary if an accurate profile of persisters and dropouts was to be constructed (Aitken, 1982; Astin, 1975, 1978; Pascarelia, 1986). 
Early attrition statistics were based on whether a student completed an associate or bachelor's degree program in the standard length of time. Willett (1983) and Lenning, Beal, and sauer (1980) pointed out that only recently had recognition been given to the fact that program completion was only one type of retention. Student retention, or student persistence, might be manifested by the completion of degree, the completion of a program that did not include the awarding of a degree, the completion of a course, or simply the attainment of an educational goal (Lenning et a1., 1980). Pappas and Loring (1985) proposed that learners be divided into three broad categories: (a) degree seekers, (b) problem solvers, and (c) cultural achievement seekers. Eddy (1980) identified drop-in retention strategies. Tinto (1987) suggested that students' educational goals, as well as their commitment to those goals, were major influences on voluntary witharawal from college. Catalano (1985) stated that models needed to be oriented toward retention.

To define persistence as the accomplishment of a degree and calculate attrition based on the number of students who did not complete a degree was incongruent with the mission of the junior and community college. It was likewise unrealistic to expect nontraditional students to be predominantly degree-seeking as opposed to having a multitude of other educational options that motivated them 
to return to college (Cross, 1983; Hughes, 1983; Kasworm, 1980; Miller, 1978; Smart \& Pascare1la, 1987).

Two major works in the field appeared in 1975: Preventing Students from Dropping Out by Alexander Astin, and Revolving College Doors by Robert Cope and William Hannah. Astin's research focused primarily on identifying ways to encourage students to complete college. Astin's study was both longitudinal and multiinstitutional in nature. However, the study was not very reliable because only a $40 \%$ rate of return from respondents was achieved. Nonrespondents, had they chosen to reply, might have changed the results. The most frequent reasons provided by both men and women for dropping out of courses were: boredom with classes, (b) financial problems, (c) dissatisfaction with requirements and regulations, and (d) changes in career goals. Astin's findings suggested that academic programs of undergraduate institutions failed to capture the interest of numerous students--including high achievers.

Cope and Hannah (1975) reviewed more than 400 studies of attrition/retention as well as related research and materials. Their conclusions were: (a) that the student withdrawal inate had been high for a number of years, with $40 \%$ of students not earning degrees in four years; (b) that there was little attrition among students who performed well in high school and on national tests; (c) that men and 
women discontinued their college studies in approximately equal proportions but for different reasons; and (d) that colleges knew little about why their students withdrew, about the withdrawal process, or about the percentage of students leaving their programs. Cope and Hannah (1975) also concluded that most data collected were without value in either predicting withdrawal or in understanding the students' complex and multifaceted reasons for discontinuance.

Conceptual Models of student Attrition According to Pascarella (1982), a model of student attrition was a representation of the factors presumed to influence decisions to drop out of an institution. The model identified interrelationships among various factors and the relationship between these factors and the dropout decision. Early research of student attrition was based on descriptive models that were atheoretical. While researchers were able to state representative correlations among numerous variables, they were unable to offer explanations as to why students made their decisions to persist or to withdraw.

Precollege characteristics were also used to predict retention. As with descriptive studies, these studies were also atheoretical and were deficient in their causal explanations (Bean, 1981). 
These atheoretical studies were directly aimed at defining strategies to decrease attrition for the benefit of an institution. Studies based on theoretical models offered explanations of why students decided to stay or leave; their results were directed at developing retention strategies, primarily for the benefit of students.

Atheoretical Models: The Descriptive Studies

Under atheoretical or descriptive models, descriptions were based on facts. Factual statements were empirical generalizations; that is, things or relationships were assumed to exist because they were seen to exist.

\section{Prematriculation Characteristics}

This conceptual framework for the analysis of student attrition came from researchers who had looked at the input characteristics of students and, on that basis, had attempted to predict the Iikelihood that a student would stay at a given institution. In general, these factors fell into three categories: academic, demographic, and financial (Lenning et al, 1980). Again, one was left with the correlates of attrition. An explanation of why these factors worked was still lacking. The value of such studies was like those of other atheoretical studies, but their outcome focused on strategies for the benefit of institutions rather than for the benefit of the students. 


$$
\text { Person-Role Fit }
$$

Models using the theory of person-role fit, Rotman (1972) focused on the relationship between characteristics of the individual and the requirements of the student's role at a particular institution. These models were complementary to the Tinto (1975) and spady (1970) models which focused on academic and social integration--namely, that students with high levels of person-role fit were likely to have high levels of academic and social integration in an institution.

Rotman (1972) used a person-role-fit model derived from the work of Biddle and Thomas (1966) to study freshman attrition at the United states Coast Guard Academy. The theory was simple and general; therefore, it could be expected to lack accuracy.

The Longitudinal-Process Models

Spady's (1970) was the first theoretical model of the dropout process. Spady's model selectively borrowed and adapted Durkheim's (1961) idea that group values and friendship support were expected to reduce suicide and, by analogy, dropout. Tinto's (1975) model was the most widely cited model of the student attrition process and was the most widely tested in empirical studies. Tinto's work was highly congruent with the work of Durkheim (1961) and spady (1970). This model stated that, in the academic system, 
goal commitment led to higher grade performance and intellectual development, which in turn led to academic interpretation, which in circular fashion led to greater goal commitment--which reduced the likelihood of the student's dropping out. In the social system, institutional commitment was expected to produce peer group and faculty interaction, which led to social integration, which in turn increased institutional commitment. Institutional commitment was also expected to reduce the likelihood of students' dropping out (see Figure I).

Pascarella (1980) developed a conceptual model of the dropout process which emphasized the importance, for students, of informal contact with faculty members. In Pascarella's model, background characteristics were expected to interact with institutional image, administrative policies and decisions, size, admissions, and academic standards. These institutional factors were expected to influence informal contact with faculty members, provide other college experiences, and affect educational outcome--all of which were expected to influence students' persistence/withdrawal decisions. Background characteristics were expected to have a direct influence on institutional factors, informal contact with faculty, other college experiences, and educational outcome. Informal contact with faculty was expected to influence other college experiences and to be influenced by 
them. Informal contact with faculty was also expected to influence educational outcome and to be influenced thereby (Pascarella, 1982).

These models had at least three things in common: (a) they described attrition as a longitudinal process, (b) each model was complex, and (c) each model found as its theoretical base the social and academic integration of the student with the institution. (This theory was developed by Durkheim (1961) to explain differences in the rate of suicide among various segments of European society.) Therefore, these models had given up simplicity to increase accuracy and--to some extent--generalizability.

\section{Bean's Industrial Model of student Attrition}

Bean's mode1 was based on employee turnover in organizations. The adaptation of this model for higher education reflected the students' interaction with the institution, including: (a) their grades, (b) the practical value of the education received, (c) the sense of self-development due to schooling, (d) the repetitiveness of school life, (e) having information related to the student's role, (f) participation in decision making, ( $g$ ) having close friends, ( $h$ ) having the courses a student wants to take, (i) being treated fairly, and (j) having membership in campus organizations (Bean, 1982). These 
variables were all expected to influence satisfaction, which in turn was expected to decrease intent to leave--intent to leave was positively related to the negative act of dropping out. Two additional variables which were external to the organization were the opportunity to transfer and the likelihood of marrying-which were directly related to the negative intent to leave or drop out.

Variables similar to the academic and social integration factors of Tinto's (1975) and Spady's (1970) models appeared among the variables of interaction with the institution that included several attitudinal variables. With this model, Bean was able to describe about 508 of the variance in dropout in a single institution. Part of the success of the model was due to the attitudinal variables and intent to leave. Another important contribution of Bean's model was the operationalization of specific elements within the person-role fit, as well as within the social integration variables from Rotman's (1972) and Spady's (1970) models.

Fishbein and Ajzen (1975) analyzed the importance of intentions in influencing behavior. This basic model indicated that behavior was preceded by an intention to perform the behavior. The immediate antecedents of intent to perform the behavior were the attitude toward the behavior and the subjective norm concerning the behavior. 
Beilefs about the consequences of a behavior influenced the subjective norm concerning the behavior. A feedback loop from the behavior itself to these beliefs completed the mode1.

Thus, the attitude and the subjective norm about a behavior lead to an intention to perform, or not to perform, the behavior. According to this model, dropout decisions at a university were the result of past behavior, attitudes, and norms--with intent as an intervening variable. Intent replaced institutional commitment as the immediate precursor of dropout decisions.

The Synthetic Model

Various elements taken from the models discussed could be synthesized into a single model of student attrition. The synthetic model identified five classes of variables--background, organizational, environmental, attitudinal, and outcome-that had either direct or indirect effect on intent to leave, which was the immediate precursor of dropping out. This model allowed researchers to identify classes of variables related in a causal sequence. Variables could also be added or deleted from the model to suit the particular needs of an institution.

Family Background and Institutional Characteristics

strong parental aspirations, or expectations, for the student to attend and complete college were correlated 
positively to persistence by Astin (1972), Bayer (1968), Hackman and Dysinger (1970), Panos and Astin (1968), Sewel and Shah (1968), Sexton (1965), Slocum (1956), and Trent and Medsker (1968). Fundamental to determining students' commitment was the influence of their families. Tinto's 1975 model emphasized that commitment included determination to completing a chosen program as well as loyalty to an institution, both of which were important to persistence and dependent upon personal characteristics and background experiences. Commitment to both program graduation and to an institution was viewed as a multidimensional process of interaction and interdependence between individuals, their families, and their prior school experiences.

Trent and Medsker (1968) reported that an individual's success in college was rooted in parental encouragement and expectation, the acceptance of family values placed on college attendance, and the internalization of these norms and aspirations. Slocum (1956) reported that only 358 of his dropout sample felt their parents were very interested in their completing college, as compared to 808 of the parents of persisters. MacMillan and Kester (1973) also reported that dropouts perceived less parental support of their educational goals than did persisters. Pantages and Creedon (1978), after reviewing conflicting research results, concluded that the relationship between parents' 
aspirations and students' persistence held true primarily when there was a quality relationship between parents and student and when the student felt an inner pressure to conform to the wishes of the parents. Conversely, dropping out could be one way in which some students asserted their independence when a good parent-child relationship was lacking.

While family characteristics also appeared to be related to success in college, research literature revealed mixed findings. According to Tinto (1987), family characteristics that were linked with persistence included: (a) the parents' occupations, (b) high expectations, (c) affluence, and (d) educated farily members (Astin, 1964, 1973; Bean, 1982; Eckland, 1964b, 1965; Eckland, Panos \& Astin, 1968; Gosman, Betty, Michael, \& Theony, 1983; Hackman \& Dysinger, 1970; Iffert, 1957; Panos \& Astin, 1968; Pantages \& Creedon, 1978; Sewel \& Shah, 1967, 1968; Sexton, 1965; Slocum, 1956; Spady, 1970; Summerskill, 1962).

Family approval of the intended major was also an important variable that influenced students' success and persistence (Bean, 1982; Lenning, 1982). Students who chose a major that was compatible with the desires of their parents were more likely to receive positive reinforcement and encouragement as they progressed through college. Research indicated that, in the presence of academic 
difficulties and negative parental pressure, students might change majors, transfer, or even withdraw.

Timmons (1972) reported that entering college simply to please one's parents was another factor associated with withdrawal. Slater (1957) agreed that any time the decision to attend college was made by a person other than the student, the probability of dropping out was greater. Although Iffert, in his landmark 1957 study, did not find this to be a major reason for withdrawal, Hackman and Dysinger (1970) as well as Marks (1967) reported findings that indirectly supported this premise. Hackman and Dysinger (1970) also found that such students were less committed, while Marks (1967) reported that dropouts were more concerned with parental attitudes and expectations. This indicated dropouts had a lower internal commitment, as well as lower aspirations and educational values. In addition, dropouts often had difficulty resolving conflicts concerning their commitment to educational values and were frequently plagued with ambiguous feelings, inner conflicts and lack of purpose (Marks, 1967; Chickering \& Hannah, 1969). This lack of congruence between the values of the institution and those of the individual-institutional fit had been studied by many researchers.

Although the spady (1971) and Tinto (1987) models-have both of which focused on personal/environmental fit--served as the basis for a great deal of retention research during 
the past decade, they have not been applied to developmental education (Bean, 1980; Rotman, 1972; Starr, Betz, \& Menne, 1972). Recently, however, Halpin (1990) used the Tinto model to determine its applicability in the analysis of persistence or withdrawal at an open door nonresidential comprehensive community college. Halpin concluded that Tinto's model had utility for researchers and administrators concerned about retention.

Although other researchers had reported the same general findings regarding committing students, there remained a dearth of published studies focused specifically on developmental students in a nonresidential, public, open-door community college (Pascarella, Duby, Terenzini, \& Iverson, 1983; Pascarella \& Wolf, 1985).

Pascare1la, Smart, and Ethington (1986) focused specifically on the long-term persistence of 2-year college students. Over a 9-year period, they examined 825 students who initially enrolled in 85 different 2-year colleges; they reported that academic and social integration were the two variables with the most consistent pattern of positive effects on persistence.

Another study conducted over two semesters by Voorhees (1987) followed re-enrollment patterns of 369 students in a community college. In voorhees' study, academic integration--as represented by a logit model consisting of persistence, grade point average, number of informal 
conversations with faculty, and number of hours spent studying--was determined not to have an independent effect on persistence. In voorhees' (1987) study, the sample included both new and continuing, full and part time, students.

Webb (1988) reviewed the Tinto model, and other models derived therefrom, focusing on their general applicability to understanding freshman attrition/retention from 2-year colleges. Webb found that if the intent of a retention-research program was to identify potential dropouts as early as possible, none of the models he reviewed was adequate for 2-year institutions. Using information that could be obtained prior to, or at the same time as, matriculation, webb further identified variables that could be used to predict retention. Scores on standard assessment tests and variables such as clear educational and degree plans were predictive of persistence. Webb's study, however, did not measure the perceived nature and quality of students' experiences with college subsequent to matriculation; therefore, webb could not explain the modifying effects that these experiences might have on prematriculation variables.

\author{
Academic Success, Achievement, \\ and Goal Commitment
}

Spady (1971) and Tinto $(1975,1987)$ reported that formal academic performance, students' previous academic 
attainments, and their educational aspirations were clearly the dominant factors in accounting for retention. Central to these theories was academic integration, consisting of both grade performance and intellectual development. Tinto (1987) suggested that intellectual development represented an intrinsic form of reward. Intellectual development was also seen as an evaluation by the student of the academic system where grades were the most visible extrinsic reward of the academic system. Grade performance was seen as a reflection of both the ability of the student and the preference by the institution for particular types of academic behavior. According to Aitken (1982), grade performance was important because institutions set a minimal level which had to be met by students in order to remain in an institution. Grades provided a feedback message as to how well students were doing relative to both an absolute standard and to their peers. Thus grade performance was the variable most commonly used in studying retention. Prediger (1965) supported this research approach by concluding that other measures appeared to predict persistence only because they predicted the grades a student would receive.

Substantial reports not only supported the correlation between grade performance and retention, but also identified grade performance as the single most important factors in predicting student persistence (Achord \& McCary, 
1974; Aitken, 1982; Astin, 1972, 1975; Blanchfield, 1971;

Brag, 1956; Conner, 1968; Fullmer, 1956; Hayes, 1981;

Lenning, 1982; Lenning et al., 1980; Little, 1959;

Morrisey, 1971; Pedrini \& Pedrini, 1977; Rever \& Kojaku,

1976; Slocum, 1956). After reviewing 35 studies on college grades and attrition, summerskill (1962) reported that one out of three dropouts occurred for academic reasons. Summerskill concluded that "the relationship between grades and attrition appears to be continuous in that the probability of dropping out varies inversely with the grade point averages throughout the whole distribution of grades at a given college" (pp. 627-657).

In spite of this supportive evidence, the relationship between grades and retention was not clearly understood. While poor academic performance correlates positively to attrition, satisfactory grades were not necessarily a predictor of retention. Summerskill (1962) reported that prediction of dropouts was more easily distinguished at the lower end of the grade scale. Spady (1971) pointed out that while students with poor grades were highly likely to drop out, students with excellent grades, especially women, might also drop out. Pantages and Creedon (1978) reported that students who were forced to drop out because of academic or disciplinary probiems accounted for many of the negative traits attributed to dropouts as a whole. Yet, according to Eckland (1964a), students who withdrew for 
other reasons were more likely to eventually be successful persisters. Hegarty (1975), Lenning et al. (1980), and Summerskill (1962) all found that the majority of students left college voluntarily--for nonacademic reasons. Furthermore, Cope and Hannah (1975), Hackman and Dysinger (1970), Lea, Sedlacek, and stewart, (1979), Pantages and Creedon (1978), and Tinto (1975, 1987) reported that students who dropped out generaliy demonstrated higher grade performance than average persisters. Research studies on dropouts based on academic competence and goal setting can be conceptualized as shown in Figure 2 .

Student's goals

High

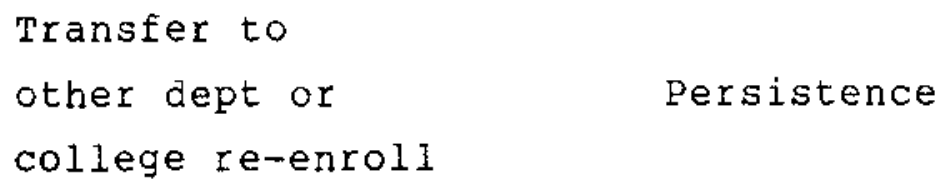

Moderate

$$
\begin{array}{ll}
\text { Depart and not } & \text { Persist until } \\
\text { re-enroll in any } & \text { forced to withdraw } \\
\text { other college at } & \text { because of failing } \\
\text { at later date } & \text { grades, etc. }
\end{array}
$$

Low

Moderate

$\mathrm{High}$

\section{Academic competency/commitment}

Figure 2. Impact/typology of goal commitment upon student retention/suicess. 
Tinto (1975) suggested that a lack of congruency between academic integration, social integration, and institutional commitment fostered voluntary withdrawal in academically competent students. Hackman and Dysinger (1970) distinguished among persisters, transfers, academic withdrawals, and academic dismissals in terms of interaction between the individuals' levels of comitment to completing college and their level of academic performance. Students who were academically competent but who had moderately low commitment tended to withoraw voluntarily, whereas students who had high levels of commitment tended to persist despite low academic competence. Students who withdraw voluntarily also tended to transfer or re-enroll at a later date rather than withdrawing permanently.

The literature provides conflicting findings regarding reasons given by students for withdrawing. Chickering and Hannah (1969), Hackman and Dysinger (1970), and Pantages and Creedon (1978) questioned the value of such information: Lenning et al. (1980) contended that student perceptions represented variables in the dropout rationale that also might operate for persisting students who became dropouts. According to Blanchfield (1971), Chickering and Hannah (1969), Cope and Hannah (1975), and Pantages and Creedon (1978), students' dissatisfaction with their grades was one of the major reasons students cited for leaving. 
Eckland (1964b) had reported that academic difficulties usually resulted in transfer or temporary dropout rather than permanent withdrawal. This observation might be linked with similar findings by slocum (1956), who reported that $51 \%$ of his research sample of dropouts had poor scholastic records in college and only 348 considered poor scholastic record to be a major factor in their decision to withdraw.

Evidently, a positive correlation existed between dissatisfaction and poor academic performance; poor academic performance was shown to have a positive correlation to low self-esteem which could hamper students' integration into the social environment of an institution. While poor academic performance might precede dissatisfaction, it could also be an outcome of dissatisfaction. Therefore, although grade reports were important in the study of retention, they were not completely diagnostic--especially among women. Hence, grade reports must be viewed within the total process of withdrawal or retention.

Information presented by summerskill (1962) indicated that the majority of the students who withdrew from college did so for other than academic reasons. Hackman and Dysinger (1970) reported that "almost all the problems reported as reasons for withdrawal by students who leave college are shared by large numbers of students who do not 
withdraw" (p. 312). Thus, there must be other factors that differentiated between those who withdrew and those who persisted in spite of academic difficulties. Therefore, the degree of commitment in terms of both educational expectations and institutional commitment was seen as a significant factor in retention.

The conceptual models by Bean (1980), Spady (1970, 1971), and Tinto (1975, 1987), discussed previously, al1 included goal and institutional commitment as major variables in the study of retention. Tinto contended that these commitments were both predictors and reflections of a person's experiences, disappointments, and satisfactions in the collegiate environment. Students who entered an institution with a sense of commitment were not only more likely to become more appropriately integrated into the social and academic systems of the college environment, but as a result of their total integration were also more likely to enhance their commitment to both the institution and to their personal educational goals. In the end, it was the interaction between goal commitment and institutional commitment that eventually determined the degree of student persistence (Tinto, 1975).

Tinto agreed that both goal and institutional commitment increased as a function of advancement toward completion of a degree. Sexton (1965) stated that perceived benefits increased as graduation neared and that 
the perceived ratio of benefits to costs increased as students progressed. This concept was supported by the fact that voluntary withdrawal became less likely as individuals approached program completion. Tinto (1975, 1987) further argued that level of goal and institutional commitment could be used to distinguish between transfers and permanent dropouts in both dismissals and voluntary withdrawals. High goal commitment with low institutional commitment could lead to transfer, whereas low goal commitment was more closely associated with permanent withdrawal. When institutional commitment was poor, high goal comitment could increase persistence, whereas when goal commitment between the needs of the student and the demands and resources of the college was poor, less importance was attached to persistence. Hackman and Dysinger (1970) supported this concept. Kamens (1971) reported increased retention rates as students' comitment to the college increased. Kamens argued that student commitment could be strengthened by the institution. According to Kamens, to the extent that student commitment can facilitate the status transition from studenthood to adult economic and occupational roles that students value, that commitment gained in its capacity to influence their commitments and self-concepts (Kamens, 1971).

Although the relationship between institutional commitment and satisfaction, as well as student retention, 
had been demonstrated with empirical data, the relationship between institutional commitment, grade performance, and retention was less evident. Spady (1971) reported that institutional commitment was largely generated early in the college career. Academic performance had no bearing on the sense of loyalty and commitment that students felt toward an institution. Spady suggested, instead, that institutional commitment represented an intrinsic set of attitudes and, as such, was not sensitive to the extrinsic academic reward system. Yet spady found that women developed institutional commitment early in their undergraduate careers. He also found that institutional commitment was a stronger determinant of retention than academically related variables.

Bean (1980) offered support to the premise that institutional commitment was the most important variable in explaining dropouts for both men and women. spady reported that, if greater comitment could be generated at all, it would be by providing students with experiences that affected the intrinsically meaningful spheres of their lives as human beings (as opposed to just students) rather than by merely attempting to modify the academic reward structure itself (Spady, 1971).

\section{Developmental Education}

During the last 2 decades, the most common point of entry to higher education has become the 2-year college 
(Halpin, 1990). Fewer than half of new college entrants now begin their higher education in 4-year colleges (Tinto, 1987). Cope and Hannah (1975) observed that the rate of dropping out among community college students was considerably higher than the rate at 4 -year colleges. After comparing the persistence rates between 4 -year and 2-year colleges, Astin (1975) reported that students of comparable ability had somewhat better chances of returning for a second undergraduate year if attendance were at a 4-year college or university rather than if attendance were at a 2-year college. Cope and Hannah (1975) found that about 2 in 10 students entering community-college stayed on to complete requirements for an associate degree, and 1 in every 10 students went on to complete the requirements for a baccalaureate degree. In the years to come, these twin themes of accountability and quality were likely to become the major issues which community colleges will have to address. Mounting concern over the perceived decline in students' aptitude and prior academic achievement, coupled with increasing interest in assessment of student learning outcome, has forced many colleges to reexamine the effectiveness of their academic programs (Lum \& Alfred, 1987).

Although research related to developmental education in community colleges has been extensive, the major portion of research on the topic has been comprised of single 
institution, system, and state level studies of the effect of ascriptive student characteristics and teaching techniques on student achievement and program completion. However, the recent focus on educational reform has raised interest in obtaining a national assessment of these programs and problems. Multiinstitutional and longitudinal studies encompassing a large number of remedial students have been attempted.

Roueche and snow (1977) reported that carefully designed developmental education programs conducted by properly trained teachers and counselors could improve the basic skills of remedial students and contribute to their success in college. Studies conducted at the University of Texas by Roueche, Baker, and Roueche (1984) identified the central components of successful programs in developmental education as being: (a) strong administrative support, (b) mandatory assessment and placement, (c) structured courses, award of credit, (d) completion strategies, (e) multiple learning techniques, (f) volunteer instruction, (g) peer tutors, (h) monitoring of student behavior, and (i) evaluation. Friedlander (1981) reported that students who felt confident of a particular skill tended to be more apt to enroll in remedial courses in institutions with a voluntary placement policy than students who were not as confident of that skill.

The first United States Department of Education examination of a postsecondary remedial education study 
reported that remedial programs were replete throughout all levels of higher education. The study revealed that 638 of the schools offering remedial courses had reported increases of 108 or more in remedial/developmental enrollment since 1978, and that between 168 and 258 of all college freshmen took at least one remedial course in reading, writing, or mathematics.

Another study, conducted in 1981, inquired extensively into the placement and assessment procedures of institutions. Findings indicated that about 308 of first-time students were academically deficient and in need of remediation. Perhaps the most striking finding was that only 38 of the responding institutions perceived that the skill level of entering freshmen was not a problem.

These studies, which described the national and institutional picture of developmental education programs, confirmed that remediation had become an important issue affecting all levels of education and that the national and institutional picture was even worse in developmental mathematics.

Perhaps the most widely quoted research studies have been those completed by Cross (1971, 1976) and Astin (1975). Cross found that developmental education students served by community colleges exhibited major differences from traditional students on characteristics such as academic achievement, family socioeconomic background, 
self-esteem, unwillingness to take chances, prior educational achievement in the family, and orientation toward vocational rather than academic subject mastery. Astin's studies focused mainly on student demographic characteristics which affected college matriculation and graduation. Significant to community colleges and their remediation efforts had been the over-representation of minorities in these institutions. "A major ctiticism centered around the contention that community colleges promote the economic and social satus quo rather than aid upward mobility" (Vaughn, 1979a, p. 2). Given the deficient academic skills and low achievement levels of students in developmental education programs, it was possible that remediation efforts in community colleges had become simply another barrier which students had to overcome in order to reach their educational goals.

Something else that needs careful examination is the demographics of part-time learners. It is commonplace to note that they are older than full-time students. It is less well known that those who primarily benefit from lifelong learning are whiter, wealthier, and better educated than those who do not. And the trend has been to widen the inequalities that exist. (Zwerling, 1980, p. 96)

Indeed, critics of the communty college have stated that equal educational opportunity may be only an illusion and that community colleges have become an integral component in the preservation of the present social class structure, abetting this sorting out process (Astin, 1975; Zwerling, 1980). These and other studies contributed to 
the understanding of remedial students and to the important role student characteristics played in influencing educational outcome.

\section{Developmental Mathematics programs}

Mathematics has become a we11-defined curriculum area which accounts for a higher percentage of community college effort than any discipline other than English composition, reading, and literature. The purpose of this section was to present a review and examinination of a selection of writings and reports that detail the status of mathematics instruction at 2-year colleges.

In a study sponsored by the National science Foundation in 1969, Beckwith (1980) reported that mathematics accounted for $24 \%$ of the 2-year college enrollments in science and social science. The committee on the Undergraduate Program in Mathematics and the Mathematics Association of America, reporting deficiencies in the curriculum in 2-year colleges in the 1960 s and 1970s, described a need for additional courses in calculus, linear algebra, and other advanced level courses of mathematics as well as for the preparation of instructors in mathematics. More recently, however, the concern of those in the upper reaches of mathematics in 2-year colleges has given way to consideration of mathematics for general education or for severely underprepared students. Beckwith's (1980) review 
of several studies of mathematics in general education included one done in the early 1970s that found two-thirds of mathematics departments offering a course specially designated for general education.

Studies of remedial mathematics have included nationwide surveys on teaching techniques, faculty qualifications, and the amount of time spent on various aspects of mathematics. Most developmental education students in community colleges have been found to be deficient in the basic skills necessary to deal with the concepts, constructs, and language of mathematics. Developmental education students tended to place little value on mathematics as a discipline. These students most often did not perceive mathematics as useful to them in their daily lives or in their career goals. Strowbridge (1987) reported that developmental education students often had a self-concept of failure. This concept had been developed through repeated experiences of failure in the educational system. Strowbridge added that personal identity, or self-concept, was a reflection of reinforcements that students received from peers, teachers, and administrators. Strowbridge's report seemed to agree with Tinto's social and institutional fit concept.

Change (1983) found that elementary algebra was offered in 828 of the college remedial courses, arithmetic in $68 \%$, and intermediate algebra in 538. Most studies indicated 
that remedial mathematics courses were offered on a noncredit basis and that almost all colleges provided tutorial services for students. In just under half of the colleges surveyed, remedial students finished developmental programs within one semester, and just over half of the remedial students completed at least one college-level mathematics course.

other studies on developmental education in mathematics revolved around questions of definition, placement of students, granting of credit, course content, and effective instructional practices rather than on success of students or success of a program. Beckwith (1980) reviewed a 1975 study which reported that nearly all 2-year colleges offered courses in developmental mathematics. At that time, less than half of the colleges surveyed required a placement examination and few of those that did mandated that students take remedial courses. The 1970 s was an era when students were given the right to fail, a procedure and value system that has changed notably in the past few years. Now, a rapidly increasing number of 2-year colleges have been returning to the 1950 s pattern of mandated placement tests as well as course placements in English and mathematics.

The literature also contained many reports from individual colleges. At Lower Columbia College (Washington), developmental mathematics was described in a 
report indicating various ways students could complete the mathematics requirements through courses offered in the laboratory and classroom. As indicated in many other colleges, the high attrition rate in developmental mathematics was combated by extensive placement testing, mathematics anxiety workshops, and several levels of review courses (Crepin, 1981). Mathematics avoidance was revealed in a study of students' course-taking patterns in a large urban commuity college district in which a high percentage of the students who had noted an interest in sciencerelated careers had completed no mathematics courses--even after having completed more than 30 units of college work (Friedlander, 1981 ).

Based on the literature, there seemed to be a split between instruction in remedial and college-level mathematics. The publications on developmental mathematics described laboratory experiences, tests, grades, auto-instructional programs, and ways of staffing the laboratories to make them more efficient. The reports on college-level mathematics discussed games, proofs, problem-solving strategies, theorems, and the concept of mathematics anxiety. There were occasional reports on merging mathematics with other fields, as for example integrating writing into the mathematics curriculum (Goldberg, 1983). In a 1983 study involving basic mathematics and women, Brunson reported that women in 
all-female sections of basic algebra classes did better than women in coed classes.

The major difference between remedial and college-level mathematics seemed to be between the manner of presentation (laboratory vs. classroom) and the make-up of the staffing (lead instructor supervising a corps of aides vs. a lone instructor in a classroom). Additional differences were cited in the center for the study of Community Colleges' National Surveys (Beckwith, 1980). Instructors of developmental classes indicated that they spent less time in lecture ( 368 vs. 498). Developmental mathematics instructors were less likely to administer A, B, C, D, and F grades ( 528 vs. $76 \%$ ). As a group, developmental mathematics instructors were younger and had less teaching experience, but were much more likely to rely on tutors ( 608 vs. $48 \%$ ) and paraprofessional aides ( $27 \%$ vs. 128) for teaching assistance as well as more likely to use text-scoring facilities ( 238 vs. 138 ).

Some work has been done recently on competencies expected of entering freshmen, with particular attention to tests that would place students in mathematics courses in which they had a reasonable chance of succeeding. Many of the questions concerning student placement had to do with the relative merits of nonstandardized versus standardized placement tests prepared and distributed by national agencies. Several reports and articles on faculty 
dissatisfaction with nationally normed tests have been published. More than 15 years earlier, Wood (1980) reported the switch from American college Test mathematics placement tests to an instrument developed at the downtown campus of the University of Houston. The college used the 50-minute test to shunt students scoring below 708 into a course reviewing algebra. Notable results in retention and achievement were effected.

A minimum level of mathematics literacy for all college-level students was specified in the 1981 annual report of the American Mathematical Association of the 2-year College Developmental Mathematics Curriculum Comittee (Dyer, 1981). Community colleges have been cooperating with universities and secondary schools in several states in announcing competencies expected. The Academic senates of California community colleges, the California state University, and the University of California addressed a statement to administrators, teachers, counselors, and parents of high school students indicating the requisite competencies in algebra, arithmetic, geometry, and advanced mathematics that students should demonstrate in preparation for college. The Southern Florida Educational Consortium, which included Miami-Dade Community College, prepared a booklet for distribution to junior high and high school students indicating expected competencies in mathematics and English 
usage (Planning your education, 1982). Other community colleges had reportedly undertaken similar projects.

Despite these pronouncements, the question of how much students knew had rarely been studied. For more than 15 years, the National Assessment of Educational Progress had administered items in science, social sciences, and mathematics to samples of 9-year-olds, 13-year-olds, and 17-year-olds. Building on this idea of assessing student knowledge in an absolute rather than a relative sense, the Center for the study of Community Colleges designed an instrument to survey community college students in the humanities, sciences, social sciences, and mathematics. Results of this study revealed that students who had completed more total college units, who were in college to transfer and/or to prepare for a career in advanced professions or technologies, or who had completed more mathematics courses scored higher. This result was expected, but the highest correlation was between mathematics scores and the question: Compared to other students at this college, how would you rate your ability to use algebra to solve problems? students were given the choice of rating themselves poor, fair, good, or excellent. Scores on the mathematics scale ranged from below 4 for students who rated themselves as poor to above 6 for those who said they were excellent (Riley, 1984). 
Strowbridge (1987) reported that developmental teachers were the key to successful learning in mathematics. At best, developmental education students had marginal mathematics skills. Their perception of mathematics was affected by past experiences, and they could not escape from the effects of past choices.

Both developmental education students and developmental education teachers must build on the assimilated past, not on what might have been if different choices had been made. Thus, the challenge in teaching mathematics to developmental education students was to build strong positive attitudes and to eradicate or modify negative attitudes toward mathematics (Strowbridge, 1987).

An effective mathematics program required not oniy provision for meeting needs but also for diagnosing and assessing attitudes, feelings, and emotions toward mathematics. Both success and achievement were key needs. Maslow (1987) listed four general areas of need: safety, love, belonging, and self-esteem; all must be accommodated if an individual was to become self-actualized.

The need to explore, investigate, discover, and create is another integral part of this set identified in the literature. John Dewey was one of the first to identify mental need. Piaget reinforced this concept through his idea of disequilibrium. Jerome Bruner further reinforced the idea with the notion that the satisfaction derived from having learned is one of the most powerful motivators available to developmental education instructor.... The need to do and the need to know are also included as segments of this more general 
need. There is, then a direct relationship between needs and basics in mathematics. (p. 17)

Krathwohl provided insight into five levels of attitude, feelings, and emotion, as well as into the sequence through which these needs were learned:

The receiving...level is...a willingness to observe, listen or realize. A willingness to engage, respond, volunteer, or practice reflects the responding level...the continued desire to grow, prefer, and assume responsibility describes the value level...orgainization and characterization include the forming of judgments and relating, revising, and consistence [italics added]. (Krathwohl, 1969, p. 89)

Therefore, if the faculty and developmental education administrators were to make the difference in meeting the students' needs, they would have to be knowledgeable in identifying and satisfying these needs. 
CHAPTER 3

METHODS AND PROCEDURES

Introduction

For this investigation, the existing data were used to identify students enrolled in developmental mathematics. This autopsy, or post hoc, design asked students about their college attendance behavior, how often they used certain academic and student services, how they evaluated those services, and about other features of their college experience such as current activities and plans for their post college future.

Theoretical construct: The Tinto model, his theories and certain variables from this model, were used as a guide to studying retention in developmental mathematics education (Tinto, 1975 ).

\section{Sample Population}

The sample population for this study was the Collin County Community College (CCCC) developmental mathematics students who had completed the developmental mathematics sequence by the spring of 1991 and who were then enrolled in college level mathematics. The CCCC aevelopmental mathematics education courses selected were entitled: 
Mathematics 151-Pre-calculus for Business and Economics and Mathematics 181-College Algebra. These courses were designed as college level mathematics courses by the Dean Astin of CCCC (personal communication, November 11, 1991). The sample population included 56 developmental education students who had completed the developmental mathematics sequence and college level mathematics in the spring and summer of 1991.

\section{Instrumentation}

The survey instrument developed for this study was the Student Information Questionnaire (see Appendix B). The instrument incorporated items developed by Pascarella and Terenzini (1983), Seale (1984), and Nora (1987). The content and predictive validity of the 55 items used to measure 3 main variables in Tinto's model was established at .84 (Pascarella \& Terenzini, 1983). Forty-eight of the items were usea in the stuay. (See Appendix E' for complete original survey instruments.) Initial factors such as comitment, academic integration, and social integration have been well documented by Pascarella and Terenzini (1983) to test Tinto's model. Subsequent investigations by Pascarella in 1986 refined the scales through a series of factor analyses and reauced the 55 items to 30 items. The construct and predictive validity of .84 for the measures were further confirmed by Pascarella and Chapman's 1983 
stuayy contrasting retention among students at different types of institutions, including 2-year colleges. Pascarella et al. (1983) and Fox (1985) also established the validity of .84 for the instrument while studying retention in a nonresidential university setting. Rendon (1982) and Nora (1987) established the construct and predictive validity of the measures with a community college population.

Additional data collection sources consisted of official forms and college records which included, but were not ilmited to, class rosters and college transcripts. Four major areas of Tinto's model were covered by the 30-item survey instrument: (a) preentry attributes, (b) goal commitments, (c) institutional experiences, and (d) personal/normative integration.

Procedures for Data Collection

Developmental mathematics students enrolled in the 1991 summer college-level mathematics courses at the central and Spring Creek campuses of the CCCC district in Texas were given an opportunity to participate voluntarily in this study. Permission to carry out the study had been granted by the Dean of Developmental Education and by the Director of Institutional Research, as well as by the Vice President for Instructions. Data were also provided by the Dean of Developmental Education. In addition: 
1. The student Information Questionnaire was administered to students/respondents by participating college instructors.

2. Each returned questionnaire was inspected for completeness.

3. The statistical Package for Social sciences (SPSS) was used to analyze the survey data.

4. The survey instrument was coded in accorance with Likert-type classifications: 5 = agree strongly, 4 = agree somewhat, $3=$ not sure, $2=$ disagree somewhat, $I$ = disagree strongly.

\section{Analysis and rreatment of Data}

The two instruments used to treat and analyze data were the Institutional Integration scale (ISS) developed by Pascarelia and Terenzini, and Students' Existing Records (SER).

The demographic variables included: gender, age, and educational levels of parents. Other variables included: (a) institutional goals, (b) institutional commitments, (c) institutional experiences, and (d) social and academic integration.

For Hypotheses l(a) through l(d), data were compiled using students' developmental education grade point average (GPA) and the parents' educational levels. The chi-square statistics were used to analyze these question to determine 
whether the sample was independent of the research population.

For Hypothesis 2, the data were prepared for automatic processing using the statistical Package for Social Sciences (SPSS). The research questions concerned: (a) students' perception of their college major, (b) the importance of good grades, (c) student performance academically as anticipated, (d) the influence of interpersonal relationships with other students, (e) personal relationships with the faculty, (f) nonclassroom interactions effect on career goals and aspirations, (g) the importance of graduation, ( $h$ ) making the right choice, (i) the likelihood of registering next semester (see Appendixes $B$ and $C$ for auestionnaires). The chi-square was used to analyze this question to test for independence of the research sample.

For Hypothesis 3 , the SPSS was used to process the data. The research questions dealing with this hypothesis concerned: (a) whether mathematics courses were intellectually stimulating, (b) satisfaction with mathematics experiences, (c) attendance of cultural events, (d) personal satisfaction with extent of intellectual development, (e) performance of recommended mathematics assignments, (f) increased interest in ideas and intellectual matter, (g) total mathematics influence on intellectual growth and interest in ideas, (h) development of personal relationships with other students, (i) 
satisfaction with student friendships, (j) influence of interpersonal relationships on personal growth, values, and attitudes, (k) äifficulty of meeting and making frienäs, (1) satisfaction with dating relationships, (m) willingness of other students to listen and to help solve problems, (n) comparison of other students' attitudes, (0) participation in organized extra-curricular activities, (p) condition of housing arrangement, (q) opportunity to meet informally with the faculty, ( $r$ ) willingness of faculty member to spend time outside of class, (s) development of close relationship with faculty, (t) result and influence of nonclassroom interaction with faculty on inteliectual growth and interest in ideas, and (u) result and influence of nonclassroom interaction with faculty on personal growth, values, and attitudes.

For Hypothesis 4, the SPSS was used to process the data, and the chi-square statistical method was used to analyze the study's findings. Research questions topics concerning this hypothesis dealt with: (a) enjoyed mathematics classes, (b) expressed views in mathematics classes, (c) had been in mathematics classes where something new was learned, (d) had been intellectually stimulated by mathematics classes, (e) had trouble keeping mind on mathematics class, (f) missed mathematics classes, (g) thought about transferring or aropping out of classes, (g) participated in group activities, (h) attended campus 
parties, (i) felt at home, (j) met other interesting students, and ( $k$ ) found interesting things to do on campus. For Hypothesis 5, student Existing Records (SER) were used to analyze the data, including: (a) placement grades, (b) developmental mathematics composite grades, and (c) college level mathematics grades. Analysis was accomplished by means of the chi-square statistical method. Chart $I$ in Appenōix $C$ shows a summary of the main hypotheses and subhypotheses, related instruments, as well as the statistical tests as they related to each other. 
CHAPTER 4

PRESENTATION AND ANALYSIS OF DATA

Introduction

One purpose of this study was to identify and describe factors related to student retention in comprehensive community college developmental education mathematics courses. A second purpose was to develop strategy for improving stuaent retention in the comprehensive mathematics programs. Therefore, this chapter presented the methods used to analyze data and discussed the results.

Research Hypotheses

Research Hypothesis 1(a)

There is no significant relationship between gender and student retention in developmental education mathematics.

Research Hypothesis 1(b)

There is no significant relationship between age and student retention in developmental education mathematics. 
Research Hyphothesis $1(\mathrm{c})$

There is no significant relationship between grade point average (GPA) and student retention in developmental education mathematics.

Research Hypothesis 1( 1 )

There is no significant relationship between parents' education and student retention in developmental education mathematics.

Research Hypothesis 2

There is no significant relationship between academic goal commitment and student retention in developmental education mathematics.

Research Hypothesis 3

There is no significant relationship between institutional experience and student retention in developmental education mathematics.

\section{Research Hypothesis 4}

There is no significant relationship between student academic involvement and student retention in developmental education mathematics. 
Hypothesis 5

There is no significant relationship between grades, performance, and student retention in developmental education mathematics.

The research hypotheses were analyzed using the Statistical Package for Social Sciences (SPSS). Data from the Institutional Integration scale (IIS) were also used to analyze research data for Hypotheses 2, 3, and 4; Student Existing Records (SER) were used to analyze research data for Hypotheses 1 and 5. The use of the .05 level of significance was appropriate for these data.

For all research hypotheses, percentage frequencies were also used to analyze data. Chi-square was used to test the variables under investigation to determine whether the frequencies observed in these categories differed significantly. The test was based on the following assumptions: The null hypotheses was that the $k$ independent samples of $n 1, n 2, \ldots . n k$ members was from the same population. The result of data analysis have been presented and discussed both numerically and statistically.

\section{Description of Sample}

In the 1991 fall semester, 56 developmental education students who were taking college level mathematics courses at Collin County Community college (CCCC) were surveyed. Completed surveys from 41 students (728) were used in this 
study. The data were obtained by administering (IIS) to the students. Analysis of the data was accomplished by using sPSS. Data describing demographic characteristics of the responding sample were derived from survey questions 5 and 6. The accuracy of this study depended upon the accuracy with which the IIS was completed by the students. The researcher's goal was to make the study consistent, clear, and simple without modifying the results.

Table 1 illustrated the different factors affecting retention: (a) age, (b) gender, (c) grade point average, (d) placement grades, and (e) parental education. The question was asked: Did a significant relationship exist between age and student retention? (see Hypothesis $1(\mathrm{~b})$. For purposes of analyses, respondents were divided into age groups: younger students $(18-24)$ and mature students (25-45). The 18-24 age group was comprised of 21 students, the 25-31 age group of 7 students, the 32-38 age group of 6 students, and the 39-45 age group of 7 for a total of 41 students. Data for this study were collected by examining SER for these students. Chi-square was used to determine whether statistical difference existed at the .05 level. (See Appendix D.)

Did a statistical relationship exist between gender and student retention? Examination of the numerical data presented some interesting findings. The number of males 
Table 1

Factors that Affect Retention

\begin{tabular}{lrrrr}
\hline$\frac{\text { Age }}{a}^{\mathrm{a}}$ & $18-24$ & $25-31$ & $32-38$ & $39-45$ \\
\hline $\begin{array}{l}\text { Gender } \\
\text { Male }\end{array}$ & 50 & 2 & 2 & 4 \\
& $\frac{11}{21}$ & $-\frac{5}{7}$ & $-\frac{4}{6}$ & $\frac{3}{7}$
\end{tabular}

parent's eoucation

Father ${ }^{\mathrm{C}}$

Not HS Grad

HS Grad

Some college 6

Bachelor/plus

$\frac{3}{15}$

32

3

5

$\frac{4}{14}$

$\begin{array}{ll}2 & 1 \\ 1 & 1 \\ 1 & 1 \\ 3 & 2 \\ 7 & 5\end{array}$

Motiner ${ }^{d}$

Not HS Grad

HS Grad 7

Some college 7

Bachelor/plus

$\frac{2}{18}$

24

4

7

1

$-2$

2
0
$-\frac{1}{5}$

2

1

7

18

Grade point average

\begin{tabular}{|c|c|c|c|c|c|c|}
\hline 0 & to & 2.0 & 4 & 1 & 1 & 0 \\
\hline $2 . i$ & to & 3.0 & 9 & 5 & 4 & 5 \\
\hline 3.1 & to & 4.0 & 8 & 5 & 4 & 5 \\
\hline & & & 21 & 11 & 9 & 10 \\
\hline
\end{tabular}

Placement graaes ${ }^{f}$

\begin{tabular}{rrrrrrr}
0 & to & 17 & 7 & 2 & 0 & 0 \\
17 & to & 36 & 10 & 5 & 3 & 7 \\
37 & to & 55 & $-\frac{4}{21}$ & $-\frac{0}{7}$ & $-\frac{3}{6}$ & $\frac{0}{7}$ \\
\hline
\end{tabular}

a $\mathrm{x}^{2}(18, \underline{N}=41)=11.3, \mathrm{P} .88$.

b $x^{2}(1, \underline{N}=41)=1.25, p .26$.

$c \mathrm{x}^{2}(3, \underline{N}=41)=1.2, \mathrm{p} \quad .75$.

$d x^{2}(3, \bar{N}=41)=4.5, p .21$.

e $x^{2}(17, \underline{N}=41)=23.50, p \quad .12$.

$\mathrm{f} \mathrm{x}^{2}(25, \underline{\mathrm{N}}+41\}=29.3, \mathrm{p} .25$. 
and females were virtually balanced among the younger age group. However, the females outnumbered the males among the more mature group. What seemed to be happening here was that, at the child bearing age, females stopped out of schoo1. Then as the years progressed (between 39-45 when their children were older) more females than males returned to school. This assumption might be based upon chance, therefore, a new study would be needed to ascertain whether females dropped out of school more at the child bearing age only to drop back in later.

Statistically, the chi-square test was used to determine whether the retention factor was from the developmental education student population. The chi-square value obtained was not significant at the .05 level for any of the factors tested. (See Appendix D.)

Did significant relationships exist between grade point average and student retention? [Hypothesis 1(c)] Responses elicited from the respondents showed that students across the age continuum, both younger and more mature students had a mean grade point average of 3.5 . However, younger students $(18-24)$ tended to have lower grade point averages than mature students (25-45). For the mature students, determination or inner drive, not grade performance, might very well be the key to success. The more mature students very likely had a strong desire to 
achieve in college. However, another study would need to be made to determine whether the mature students' college grade point average reflected their high school grades. Similarly, a new study might be needed to ascertain whether mature students' college grade point averages were reflections of their high school grades. The chi-square value obtained was not significant at the .05 level for grade point averages. (See Appendix D.)

Did significant relationships exist between placement grades and student retention? (Hypothesis 5.) Examination of the numerical data presented some interesting findings. Placement grades ranged from 0 to 55 . These were the composite grades the students received in the developmental mathematics program. More younger than mature students received poor grades ( 7 vs. 2). Mature students tended to maintain a balance between scoring too low or scoring too high $(\underline{M}=27, \underline{S D}=4.25)$. The younger students' grades tended to be negatively skewed $(\underline{S K}=-6.3)$. The chi-square obtained for Hypothesis 5 was not significant at the .05 level for placement grades. (See Appendix D.)

Did significant relationships exist between parents' educational levels and student retention? [see Hypothesis l(d).] Numerical examination of the existing data presented some interesting findings. More of the students' fathers (298) than mothers (228) had graduated from college. More parents of the 18-24 age group (788) had 
graduated from college. The number of parents with a college education dropped off as the ages of the students' increased. In the 39-45 age category, there were almost no parents with college educations--which might suggest that parents of these students had not had the opportunity to attend college. The chi-square test was used to analyze the data. The value of the chi-square obtained for Hypothesis $1(d)$ was not significant at the .05 level for parents' education. (See Appendix D.)

Did a significant relationship exist between academic goal commitment and student retention in developmental mathematics education? (Hypothesis 2.) The data elicited from the Institutional Integration scale (IIS) survey instrument questionnaire have been presented in Table 2 . The Likert-type survey questions presented here were used for study and analysis, were numbered consecutively according to the survey instrument (see Appendix B) and have been presented here as listed in numerical order in Table 2:

7. I have no idea at all what I want to major in.

9. Getting good grades in developmental mathematics is not important to me.

10. I have performed academically as well as I anticipated I would.

11. My interpersonal relationships with other students have had a positive influence on my intellectual growth and interest in ideas. 
Table 2

Academic Goal Commitment vs. Retention

\begin{tabular}{|c|c|c|c|c|c|}
\hline Q. NO. & $\begin{array}{l}\text { Agree } \\
\text { strongly }\end{array}$ & $\begin{array}{l}\text { Agree } \\
\text { somewhat }\end{array}$ & $\begin{array}{l}\text { Not } \\
\text { sure }\end{array}$ & $\begin{array}{l}\text { Disagree } \\
\text { somewhat }\end{array}$ & $\begin{array}{l}\text { Disagree } \\
\text { strongly }\end{array}$ \\
\hline 7 & 3 & 7 & 5 & 6 & 20 \\
\hline 9 & 1 & 5 & 1 & 5 & 29 \\
\hline 10 & 5 & 19 & 5 & 9 & 3 \\
\hline 11 & 12 & 14 & 6 & 6 & 3 \\
\hline 23 & 6 & 9 & 5 & 9 & 12 \\
\hline 26 & 5 & 10 & 15 & 6 & 5 \\
\hline 31 & 33 & 1 & 2 & $I$ & 4 \\
\hline 32 & 7 & 10 & 6 & 6 & 12 \\
\hline 33 & 26 & 7 & 5 & 3 & 0 \\
\hline 34 & 15 & 6 & 9 & 2 & 9 \\
\hline
\end{tabular}

Note. $\quad x^{2}(13, \underline{N}=41)=16, \underline{p} .25$.

23. This past year, I have developed a close personnel relationship with at least one developmental mathematics faculty member.

26. My nonclassroom interaction with developmental mathematics faculty this year have had a positive influence on my career goals and aspirations.

31. It is important for me to graduate from college. 
32. It is not important for me to graduate from collin county Commity college.

33. I am confident that I made the right decision in choosing to attend community college.

34. It is 1 ikely that I will register at community college next fall.

For survey question 7 , almost half of the respondents agreed strongly that they had established their academic goals. More than $70 \%$ agreed strongly that getting good grades in developmental mathematics was important. Almost half of the respondents agreed somewhat that they had performed academically as well as they had anticipated; 198 felt that their interpersonal relationship with other students had exerted a positive influence on their intellectual growth and interest in ideas. Thirty-seven percent were not sure whether their nonclassroom interactions with developmental mathematics faculty had influenced positively their academic goals and aspirations. More than $80 \%$ of the respondents agreed strongly that it was important for them to graduate from college while 298 believed they would graduate from commity college. However, $63 \%$ agreed strongly that they had made the right decision in choosing to attend community college, and 378 agreed strongly that they would register at comminity college next fall. The value of the chi-square obtained for Hypothesis 2 was not significant at 
the .05 level for academic goal commitment. (See Appendix D.)

Did a significant relationship exist between institutional experience and retention in developmental education mathematics? (Hypothesis 3.) The data elicited from the IIS survey questionnaire were presented in Table 3.

Table 3

Institutional Experience vs. Retention

\begin{tabular}{|c|c|c|c|c|c|}
\hline Q. No. & $\begin{array}{l}\text { Agree } \\
\text { strongly }\end{array}$ & $\begin{array}{l}\text { Agree } \\
\text { somewhat }\end{array}$ & $\begin{array}{l}\text { Not } \\
\text { sure }\end{array}$ & $\begin{array}{l}\text { Disagree } \\
\text { somewhat }\end{array}$ & $\begin{array}{l}\text { Disagree } \\
\text { strongly }\end{array}$ \\
\hline 1 & 5 & 11 & 1 & 6 & 16 \\
\hline 2 & 20 & 10 & 7 & 3 & 1 \\
\hline 3 & 7 & 8 & 5 & 14 & 7 \\
\hline 4 & 22 & 20 & 4 & 4 & 1 \\
\hline 5 & I7 & 14 & 3 & 4 & 3 \\
\hline 6 & 8 & 17 & 6 & 4 & 6 \\
\hline 12 & 8 & 13 & 7 & 8 & 5 \\
\hline 13 & 14 & 11 & 4 & 9 & 3 \\
\hline 14 & 9 & 16 & 11 & 3 & 2 \\
\hline 15 & 5 & 8 & 7 & 8 & 13 \\
\hline 16 & 5 & 7 & 10 & 4 & 15 \\
\hline 17 & 0 & 10 & 9 & 13 & 9 \\
\hline 18 & 6 & 7 & 17 & 9 & 2 \\
\hline 19 & 8 & 10 & 13 & 4 & 6 \\
\hline 20 & 19 & 12 & 5 & 3 & 2 \\
\hline 21 & 10 & 16 & 11 & 3 & 17 \\
\hline 22 & 4 & 3 & 6 & 11 & 17 \\
\hline 24 & 9 & 9 & 13 & 5 & 5 \\
\hline 25 & 6 & 11 & 12 & 8 & 4 \\
\hline 27 & 3 & 12 & 7 & 4 & 15 \\
\hline 28 & 4 & 10 & 5 & 7 & 15 \\
\hline 29 & 15 & 11 & 9 & 5 & 1 \\
\hline
\end{tabular}

$\mathrm{a} \mathrm{X}^{2}(21, \mathrm{~N}=41)=25, \mathrm{p} .24$. 
The results of the Jikert-type survey questions used for the study were illustrated in Table 3 . Typical questions related to Hypothesis 3 were:

1. Few of my mathematics courses this year have been intellectually stimulating.

4. I am satisfied with the extent of my intellectual development this year.

8. My developmental mathematics experience this year has had a positive influence on my intellectual growth and interest in ideas.

Numerically, the table revealed some interesting responses. Almost half of the respondents agreed strongly that the developmental mathematics courses they had taken had been intellectually stimulating and that they were satisfied with their community college experiences. Thirty-four percent of the respondents disagreed somewhat that they were more likely to attend a cultural event on campus than they were a year ago. Half of the respondents agreed somewhat that they were satisfied with the extent of their intellectual development this year. Forty-one percent agreed strongly that they did their outside-ofclass assignments. The respondents were equally distributed between agree strongly and agree somewhat as to whether they had increased their interest in ideas and intellectual matters. Almost half of the respondents were not sure whether most other students at the community college had values and attitudes that were different from 
theirs, nor were they satisfied with the opportunities to participate in extra-curricular activities. Most of the respondents were happy with their dating relationships as well as with their housing arrangements. A majority of the respondents agreed somewhat that they were satisfied with their opportunities to meet and interact informally with faculty members. Similar numbers of respondents felt that the mathematics faculty members were not outstanding or superior teachers, and neither did they have genuine interest in the students. Most respondents agreed strongly, however, that most developmental mathematics faculty were genuinely interested in teaching and were interested in helping students grow in more than just academic areas. The value of the chi-square obtained for Hypothesis 3 was not significant at the .05 level. (See Appendix D.)

Did significant relationships exist between student academic involvement and retention in developmental education mathematics? The data elicited from the IIS survey were presented in Table 4.

The Likert-type responses to the questions listed here compare to the numbering in the survey:

35. Enjoyed your developmental mathematics classes.

36. Expressed your views in developmental mathematics class.

37. Had developmental mathematics outside-of-class assignments that were learning experiences. 
Table 4

Student Academic Involvement vs. Retention ${ }^{a}$

\begin{tabular}{|c|c|c|c|c|}
\hline Q. No. & $\begin{array}{l}\text { Almost } \\
\text { never }\end{array}$ & Sometimes & often & $\begin{array}{l}\text { Almost } \\
\text { always }\end{array}$ \\
\hline 35 & 4 & 11 & 8 & 18 \\
\hline 36 & 9 & 13 & 9 & 10 \\
\hline 37 & 11 & 8 & 13 & 9 \\
\hline 38 & 3 & 7 & 10 & 21 \\
\hline 39 & 5 & 11 & 12 & 13 \\
\hline 40 & 19 & 11 & 5 & 6 \\
\hline 41 & 28 & 7 & 4 & 2 \\
\hline 42 & 25 & 4 & 3 & 9 \\
\hline 43 & 32 & 3 & 3 & 2 \\
\hline 44 & 13 & 18 & 7 & 3 \\
\hline 45 & 35 & 3 & 2 & 1 \\
\hline 46 & 41 & 8 & 1.1 & 11 \\
\hline 47 & 16 & 12 & 12 & 11 \\
\hline 48 & 19 & 12 & 6 & 4 \\
\hline
\end{tabular}

$\mathrm{a} \mathrm{x}^{2}(23, \underline{\mathrm{N}}=41)=25.4, \underline{\mathrm{p}} .32$.

38. Been in developmental mathematics classes where you learned something new.

39. Been intellectually stimulated by the material covered in a developmental mathematics class. 
40. Had trouble keeping your mind on what was going on in developmental mathematics class.

41. Missed a developmental mathematics class.

42. Thought seriously about transferring to another school.

43. Thought seriously about dropping out of school for a while.

44. Done things with a group of other students.

45. Attended campus parties.

46. Felt at home here.

47. Met other students who were really interesting.

48. Been able to find interesting things to do on-campus.

The respondents were asked to rate their involvements with academics as almost never, sometimes, often, and almost always. Numerical analysis of the survey revealed some interesting responses. Most of the students indicated that they enjoyed developmental mathematics classes, were in development classes where they learned something new, and were intellectually stimulated by the materials covered in developmental mathematics classes. A majority of the respondents almost never had trouble keeping their minds on what was going on in developmental mathematics classes, never missed deveiopmental mathematics classes, never thought seriously about transferring or dropping out. Few, however, attended campus parties. It might be interesting 
to study the reasons why these students almost never attended campus parties, but doing so was beyond the scope of this study.

The chi-square statistical test of independence was used to analyze the data for Hypothesis 4. The value of the chi-square obtained for student academic involvement was not significant at the .05 level. (See Appendix D.)

\section{Summary}

Failure to Reject the Null Hypotheses

Research Hypothesis l(a) stated that gender had no significant relationship with student retention in development education mathematics. The numerical evidence showed that for the younger college age students the number of males and females were almost equal. However, females outnumbered males in the more mature age categories. The results of statistical tests $\left[\mathrm{x}^{2}(1, \underline{\mathrm{N}}=41)=.25, \mathrm{p}\right.$ .88.] were not significant at the .05 level; therefore, there was not sufficient evidence to accept the alternative of null Hypothesis 1 (a) concerning the relationship between gender and student retention.

Research Hypothesis $1(b)$ stated that there was no significant relationship between age and retention in developmental education mathematics. Both younger and more mature students were represented. The results of statistical tests $\left[\mathrm{X}^{2}(18, \underline{\mathrm{N}}=41)=11.3 \underline{\mathrm{p}} .88\right]$ were 
not significant at the .05 leve1; therefore, there was not sufficient evidence to accept the alternative of null Hypothesis $1(\mathrm{~b})$ concerning the relationship between age and student retention.

Research Hypothesis I(c) stated that there was no significant relationship between grade point average and retention in developmental education mathematics. Across the age continuum, students who had received poor grades as we11 as students with good grades were retained in the program. The results of statistical tests $\left[\mathrm{X}^{2}(17, \underline{\mathrm{N}}=\right.$ $41)=23.5, \underline{p} .13]$ were not significant at the .05 level; therefore, there was not sufficient evidence to accept the alternative of null Hypothesis $1(\mathrm{c})$ concerning the relationship between grades and student retention.

Research Hypothesis I(d) stated that there was no significant relationship between parents' educational levels and retention in developmental education mathematics. Parents' educational level varied from not graduating from high school to graduating from college. Students of the developmental mathematics programs had parents in both categories. The results of statistical tests [mothers: $\mathrm{x}^{2}(3, \underline{\mathrm{N}}=41)=4.5, \underline{\mathrm{p}} .21$; fathers: $\left.\mathrm{x}^{2}(3, \underline{\mathrm{N}}=41)=1.2, \underline{\mathrm{p}} .75\right]$ were not significant at the .05 level; therefore, there was not sufficient evidence to accept the alternative of null Hypothesis $1(d)$ concerning the relationship between parental education and student retention. 
Research Hypothesis 2 stated that there was no significant relationship between academic goal commitment and retention in developmental education programs. While most of the students retained in developmental mathematics strongly agreed that they had established their academic goals, received good grades, performed academically as well as anticipated, and felt it was important for them to graduate from college, those who were not retained may have had similar academic goals. The results of statistical tests $\left[\mathrm{X}^{2}(13, \mathrm{~N}=41)=16, \mathrm{P} .25\right]$ were not significant at the .05 level; therefore, there was not sufficient evidence to accept the alternative of null Hypothesis 2 concerning the relationship between academic goal commitment and student retention.

Research Hypothesis 3 stated that there was no significant relationship between institutional experience and retention in developmental education mathematics. Most of the students who were retained in the developmental mathematics programs had undergone both negative and positive institutional experiences. The results of statistical tests $\left[\mathrm{x}^{2}(21, \underline{\mathrm{N}}=41)=25, \underline{\mathrm{p}} .24\right]$ were not significant at the .05 level; therefore, there was not sufficient evidence to accept the alternative of null Hypothesis 3 concerning the relationship between institutional experience and student retention. 
Research Hypothesis 4 stated that there was no significant relationship between academic involvement and retention in developmental education mathematics. A majority of the retained students in the sample were academically involved, although some were not. In spite of these variations in academic involvement, students continued to progress in the program. The results of statistica] test $\left[\mathrm{x}^{2}(23, N=41)=25.4, \underline{\mathrm{p}} .32\right]$ were not significant at the .05 level; therefore, there was not sufficient evidence to accept the alternative of null Hypothesis 4 concerning the relationship between academic involvement and student retention.

Research Hypothesis 5 stated that there was no significant relationship between placement grades or student performance and retention in college level developmental education mathematics. Placement grades ranged from 0 to 55, and respondents from every age category scored high. The results of statistical tests $\left[\mathrm{X}^{2}(25, \underline{\mathrm{N}}=41)=29.3, \underline{\mathrm{p}}=.25\right]$ were not significant at the .05 level; therefore, there was not sufficient evidence to accept the alternative of null Hypothesis 5 concerning the relationship between placement grades and student retention.

On the whole, despite the failure to reject the null hypotheses, this study had some interesting findings. Males and females were balanced at the younger age 
group level, but the number of females exceeded the number of males among the more mature age groups. Across the age continuum, and for both younger and more mature students, relatively high grade point averages were maintained. More of the students' fathers than mothers had graduated from college. Statistically, age, gender, grade point average, and parents" educational level were not significant. Academic goal commitment, institutional experience, academic involvement and placement grades were also insignificant for the study sample. Therefore, additional study needs to be done to determine factors affecting student retention in developmental mathematics programs at the community college level. 
CHAPTER 5

SUMMARY, CONCLUSIONS, AND RECOMMENDATIONS

\begin{abstract}
Summary
The purpose of this study was to identify and describe factors relating to stucent retention in comminty college developmental mathematics courses. The study employed Tinto's (1975) model to examine different factors relating to developmental mathematics student retention, and to provide data for the purpose of understanding retention in developmental education mathematics programs. A comprehensive review of literature focused on: (a) historical perspective; (b) conceptual models of attrition; (c) family background and/or institutional characteristics; (d) academic success and/or achievement and goal commitment; (e) developmental education; and (f) developmental mathematics programs.

Data for this study were collected using Institutional Integration Scale (IIS) and Students Existing Record (SER). The institutional integration scale was developed and tested by Pascarel1a and Terenzini (1983) to discern student retention in colleges. For this investigation, data from the SER were used to identify students enrolled
\end{abstract}


in developmental mathematics. The autopsy, or post hoc, design was the method employed to carry out the study. The survey instrument was completed by a sample of 41 students the 56 developmental education students who were retained through the developmental mathematic programs and were taking college level mathematics. The SER were obtained from the community college records of these students. The chi-square statistics were used to treat the data collected from both the IIS and the SER. The data were tested at the .05 level of significance. The use of the term sample refers to the responding sample.

\section{Findings and Discussion \\ of Data Analysis}

In the younger college age group, male and females were balanced, with the number of females exceeding males among the more mature age group. The students' ages ranged from 18 to 45 years. Across the age continuum, both younger and more mature students maintained a high grade point average. However, the younger college-age students tended to have lower grade point averages than the more mature college-age students' group. The grade point average differences seemed to reflect the high school grade patterns of the younger college-age students as well as their strong determination to succeed. The more mature 
students tended to maintain a balance between scoring too low or too high.

More students' Eathers than mothers had graduated from college. The 18-24 age group had more parents who had graduated from college than students in any other age categories. The number of parents with college education dropped off as the age of the students increased.

statistically, age, gender, grade point average, and parents' education were not significant factors for retention in developmental education mathematics. In Tinto's (1975) conceptual model of retention/attrition, age, gender, grade point average, and parents' education were used, based on the premise that past behaviors and characteristics might be expected to influence future betaviors (Bean, 1980, 1982; Bean \& Metzner, 1985; Nelson, Scott, \& Bryan, 1984). Developmental education mathematics students were at the very beginning of what would be their college endeavors. Past behaviors and characteristics were mostly those of high school behaviors that were different from college experience and accountability. Thus, the background and defining factors: age, gender, grade point average, and parental education seemed not to hold for developmental education mathematics students.

The findings that age, gender, grade point average, and parents' education did not have a significant direct effect on retention of students in developmental education 
mathematics was consistent with the findings of Bean and Metzner (1987), who reported that these variables exhibited an almost exclusively indirect, rather than direct, effect on retention. These variables primarily influenced retention decisions through direct effect on intent to go through the developmental education mathematics programs in order to open other doors. The idea of the intent to succeed variable needs to be further investigated.

The relationship between grade point averages and retention was not clearly understood (Spady, 1971). Poor or good academic performance correlated both positively and negatively in retention studies. Spady contended that satisfactory grade performance led to increased social integration which increased satisfaction, and which in turn increased commitment and retention. Tinto (1975) argued that goal commitment led to high grade performance, which further enhanced goal commitment and retention. However, dependence between staisfaction and retention was not a factor in the data for this study.

Developmental education students differed from typical college or university students in these relationships in that grade point average or academic achievement might not have been a factor in determining retentions in developmental education mathematics programs. Students taking developmental education mathematics were not forced out unless they decided to do so on their own. Retention 
in developmental education mathematics seemed, therefore, to be based on the individual student's intent to continue their studies--irrespective of getting good grades.

Most of the students, but not all, had established their academic goals, bad performed academically as well as anticipated, and felt it was important to graduate. overall, academic goal commitment was not significant in keeping students in developmental education mathematics. This statistical finding supported the findings of Bean (1980), Spady (1970), and Tinto (1975), who contended that increased social integration also increased goal commitment and retention. Developmental education mathematics students experienced a different social environment, and differed in social integration, perhaps significantly, from a typical students in a residential college and university setting. Most of the students did not normally interact with their developmental mathematics faculty, nor with their fellow students, to bring about the kind of social integration rinto addressed. In this respect, the dynamics of social integration (as contended by Bean, spady and Tinto) was lacking; hence, whether the student was committed to the academic goal or not played little part in retention. Goal commitments represented an intrinsic set of attributes that were not sensitive to the extrinsic reward system. 
Both negative and positive institutional experiences were observed or measured. The students had positive experience within the classroom setting and the content of their work; however, students of developmental education mathematics were not actively involved in student life. They had poor perception of faculty concern for quality teaching anā student development. Institutional experience did not seem to be significant for retention in developmental education mathematics.

In Tinto's 1975 model of instituional departure for younger students, social integration had demonstrated a strong relationship to retention (Bean, 1980, 1982; Bean \& Metzner, 1985). However, for developmental education students at a commuter institution, especially a 2 -year college, retention behavior aid not appear to be dependent upon institutional experience (Malin, Bray, Dougherty, \& Skinner, 1980; Bean and Metzner, 1987; Pascarella, Duby, Terenzini, \& Iverson, 1983).

In this study, the majority $(80 \%)$ of the respondents indicated that the community college was their first choice. Laman (1989) reported that an almost equal number of returning and nonreturning students made the institution they attended their first choice. This was the same conclusion reached by other researchers. Bean and Metzner (1987) reported that the social integration factor did not have a significant direct influence on arop out decisions. 
The majority of the developmental education mathematics students were academically involved, although some were not. Academic involvement was not significant for retention in developmental education mathematics.

In Tinto's model, academic involvement was predicted to have a direct effect on retention. Bean and Metzner demonstrated that acadenic factors were associated with college grade point averages that, in turn, significantly affected retention (Bean and Metzner, 1987). As reported earlier, college grade point average for developmental education students in this study had an insigniticant relationship with retention.

The majority of the students reported that they did not enjoy developmental education mathematics classes, nor were they intellectually stimulated by materials covered in developmental mathematics. However, when responaing to the question that rateo their developmental mathematics attendance recor $\vec{a}$, the majority indicated that they did not miss a single class. It might have been possible that developmental education mathematics students stayed in class they needed to master the material to pave the way to college level programs, or because they wished to succeed in the Texas Academic skill Program (TASP).

Placement grades varied from low to high for all age categories. Placement grades and college level mathematics performance were independent of retention in developmental 
education mathematics courses. As pointed out earlier in this study, the relationship between any form of grade performance and retention was not clearly understood (Spady, 1971). For developmental education mathematics courses, the possible explanation for these findings was that students were placed in the developmental education courses according to their mathematical ability in the developmental mathematics sequence; therefore, they progressed at their own pace and were retained independent of their placement grades. The students were allowed an unlimited number of trials in the devezopmental mathematics sequence; thereby, all those with high intent or determination were retained. This, however, had a carryover effect that was not sensitive to college leveI mathematics retention. High or low placement grades, therefore, seemed to have no significance in relation to college level mathematics retention. Students could be retained in the developmental education program, but might later decide to withdraw from the college level mathematics program.

These findings, that placement grades did not have a significant relationship with retention in college level mathematics, were consistent with the findings of Bean and Metzner (1987), who reported that these variables exhibited an almost exclusively indirect effect on retention. Research by both Hecklinger (1972) and Roef (1974) indicated that students who had definite career plans were 
more likely to be retained, which might account for the this sample's findings of the effect of students' retention or withdrawal from college level mathematics programs.

\section{Conclusions}

Within the context of the surveyed population and the findings of this study, the following conclusions appear to be warranted:

1. Age, gender, and parental education appear not to play a significant role in retention in developmental education mathematics.

2. Developmental education mathematics teachers appear to make the difference in retention of students in developmental education mathematics.

3. Because retention in developmental education mathematics courses appears to be independent of age, gender, and parents educational levels, retention strategies that would enhance the potential benefit of developmental eaucation should be encouraged.

4. Students with established academic goals' commitment appear not to be typical of the students retained in developmental education mathematic. Students who do not complete the developmental education mathematic also appear to have similar goals commitment. 
5. Institutional experiences appear not to play a major role in developmental education mathematics student retention.

6. Placement grades and student performance in college level mathematics is independent of student retention.

7. Developmental education mathematics students lack extra-curricular activities that would bring them together outside of the classroom.

\section{Recommendations for Further Research}

In the light of some of the patterns that appear to reveal themselves in the numerical results of the questionnaire, further research is needed:

1. To recruit more mature students who might have been filtered out of college level programs and/or career choices by retention in developmental education mathematics.

2. To identify and encourage more mature students whose career interests require a strong background in mathematics.

3. To determine the role college and job proximity factors have on retention in developmental education mathematics programs.

4. To test the impact of rASP on retention in developmental education mathematics.

5. To determine whether more women than men ärop out of developmental education mathematics programs at the child bearing age, only to drop in later when the children are older. 
6. To study the correlation between high school mathematics performance and developmental education mathematics performance on retention in developmental education mathematics.

7. To study the effect of intent to stay decisions on retention and performance in developmental education mathematics for both younger and more mature students in college or university settings.

8. To study the type of cultural and extra curricular activities that, on commuter community college campuses, inight attract younger and more mature students alike.

9. To establish nonclassroom activities timed to embrace the younger as well as the more mature developmental mathematics students.

10. To establish, as a motivational tool, a developmental mathenatics contest that would reward both talented students and committed faculty members. 


\title{
FACTORS RELATED TO STUDENT RETENTION IN COMMUNITY \\ COLLEGE DEVELOPMENTAL EDUCATION MATHEMATICS
}

\author{
DISSERTATION
}

\author{
Presented to the Graduate Council of the \\ University of North Texas in Partial \\ Fulfillment of the Requirements
}

For the Degree of

DOCTOR OF PHILOSOPHY

By

\author{
Udoudo J. Umoh, B.S., M.S. \\ Denton, Texas \\ August, 1992
}


APPENDIX A

CORRESPONDENCE

Letter Requesting Permission to Use Instrument

Letter of Permission for the Instrument

Letter of Permission for the Research study

Letter to the student 


\title{
- 15 \\ Lniversity of North Texas
}

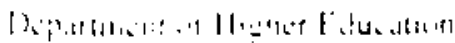

( . vils?

\author{
330 Edgewood Drive $\$ 1029$ \\ Garland, TX 75042 \\ Tel. (214) 272-0403 \\ June 12. 1991
}

Dr. Patrick Terenzini
Director of Institutional Research
3 n Administration
itaie University of New York
Abbany, NY 12222
Dear Dr. Terenzini:
SUBJECT: - Request for Permission

I am currently working on my doctoral dissertation at the University of North Texas, Denton, Texas. The topic of my study is "Factors Related to student Retention in Community College Develofmental Mathematics." The study is being conducted to fulfill a requizement for tie completion of my doctoral studies at the University of North Texas.

The survey instrument I propose to use in this study is "Institutional Integration scales" which you and your coileagues consstructed in 1979. I would like your permission to use this instrument in my study and to modify it if necessary.

Full credit would be given to you and your colleagues, as the authors of the questionnaire.

Your early and favorable response will be highly appreciated. Yours Sincerely

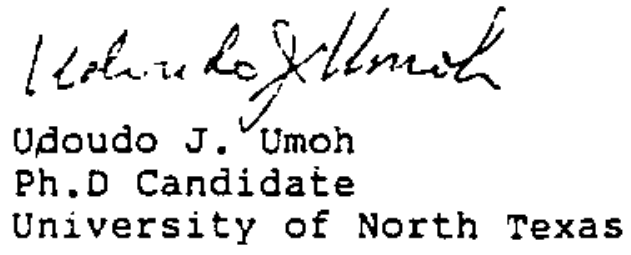

cc: Dr. Al Smith (Chairman of my Committee) Professor of Higher Education and Student Academic Advisor 


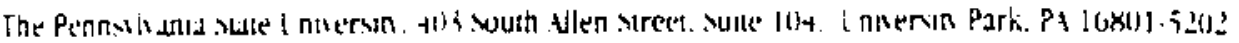

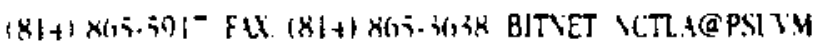

July 18,1991

Mr. Udoudo J. Umoh

University of North Texas

Department of Higher Educarion

College of Education

P.O. Box 13857

Denton, TX 76203-3857

Dear Mr. Umsh:

Thank you for your letter inquiring about the "integration scales"

Ernest T. Pascarella and I developed to operationalize the constructs of Tinto's model of college student attrition and retention. Enclosed is a copy of an instrument we used at SUNY-Albany. The items for the scales begin at the top of Page 3. Information on the scales' psychometric properties is given in:

Pascarella, E.T., \& Terenzini, P.T. (1980). Predicting persistence and voluntary dropout decisions from a theoretical model. Journal of Higher Education, 21, 60-75.

Terenzini, P.T., Lorang, W.G., \& Pascarella, E.T. (1981). Predicting freshman persistence and voluntary dropout decisions: A Replication. Research in Higher Education, 15, 255-265.

Fox, R. N. (1984). Reliability and discriminant validity of institutional integration scales for disadvantaged college students. Educational and Psychological Measurement, 44, 1051-1057.

If you have not found it already, I also recommend that you cọnsult New Directions for Institutional Research, No. 36, edited by Pascarella and entitled "Studying Student Attrition." It contains several good chapters, one of them on various resources, inciuding possible instruments (Chapter 7).

These scales and the items comprising them are not copyrighted. Dr. Pascarella and I ask only that you acknowledge the source of the scales in any reports that you prepare and that you send us copies of any published journal articles based on these scales.

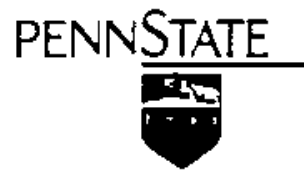

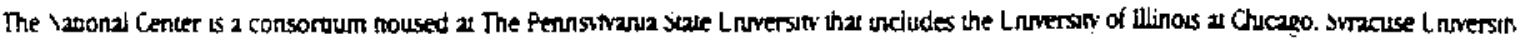

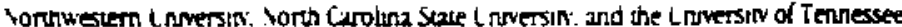


Mr. Lidoudo J. Umoh

July 18,199 !

Page 2

I hope some of this is useful to you. Thank you for your interest.

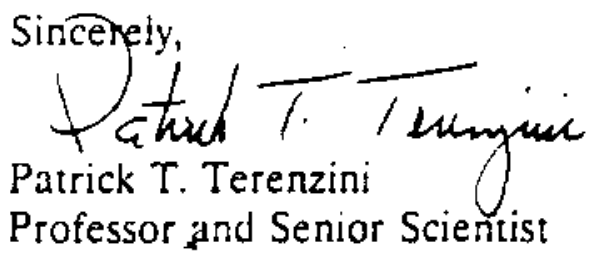

PTT/

Enclosure 


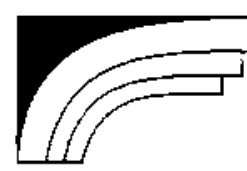

\section{Collin County Community College}

contral Compus

2200 W. University Drive

Mckinnoy, Toxas 75070

Soring Crank Cempus

2800 E. Soring Croek Parkway

(214) $546-6790$

Ptano, Texas 75074

(214) $881-5790$

August 13,1991

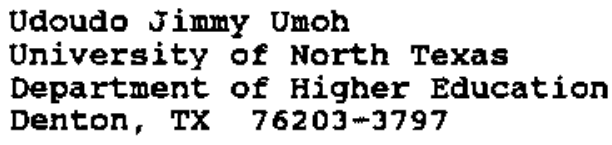

Dear Mr. Umoh:

This letter grants permission for you to conduct research on "Factors Related to student Retention in Community College Developmental Mathematics" at coll in county Community college. The dean of developmental education, Juanita Austin, supports your research and will keep me abreast of your progress.

If you have any questions, please contact me at (214) $881-5801$.

\section{sincerely,}

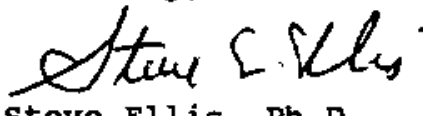

Steve Ellis, Ph.D.

Collepe Ganos:

Vice President of Instruction

Cinery cone

Tino Trujilo Vice Chermen

Sue willed Oine Secrwary

Jarmes Dideson Frassuree

E.T. Boon

J.R. (800) Collins

Gavy Z. Harns

Gleme W. dustoces

Margarat F. Raynouts

Proudons:

Jonn H. Anthony 
Dear student,

Here at the University of North Texas, we have currently underway a research project involving students who have completed their developmental education at the Collin county community college. In order for the study to accomplish its objectives, we need your cooperation

Enclosed is a questionnaire we would like to have you complete and return to us. To complete the questionnaire will only take a few minutes of your time. Will you please help us? Simply complete the questionnaire and return to your instructor. It will greatly facilitate our research effort if you return your completed questionnaire to your instructor on the day it is administered.

A very special note of thanks for your assistance. Without it, our research cannot be accomplished.

Sincerely,

Jimmy Umoh 
APPENDIX B

STUDENT INFORMATION QUESTIONNAIRES 


\section{Student Information Questionnaire}

The following questionnaire was developed to learn more about your experience with the Comprehensive Commuity College Developmental Education program. The intent of these questions is to discover how developmental education program completers differ from non-program completers so that suggestions can be made and action taken to improve services and programs for you and future students.

Please answer each question by circling the number beside your answer unless instructed to do otherwise. Also, it is requested that the answers you provide be examined in relation to other information kept in the Registrar's office. All information will be kept in strict professional confidence and will not be a part of your official record. All replies will be maintained in confidential files and results reported in group form only; individual answers will not be identified. 
Items Representing Scales

I. EAMILY BACKGROUND

Socioeconomic status (a) Parent Combined Annual
Income

socioeconomic status

(b) Mother's Formal Education

(c) Father's Formal Education ("Grammar School" to Graduate Degree)

II . PRE-COLLEGE SCHOOLING

High School Grades

Academic Aptitude (Combined Scholastic Aptitude Test (SAT) Scores)

II. PRE-MATRICULATION ON-CAMPUS EXPERIENCES

1. Before you attended collin County Community College, how many times did you visit a col- lege campus?

2. Considering all your visits to college campuses, what was the total number of days you spent on a college campus?

3. How many times did you talk to any college official or teacher while on campus?

IV. INITIAL COMMITMENTS

Goal Commitment

1. When I first attended collin county Community College, it was very important for me to get a college degree.

2. When I first attended Collin County community College, getting good grades was very important to me.

3. When I first attended collin county Community College, it was very important for me to accomplish my educational goals.

4. When you first attended Collin county Community College, what was your educational goal? 
Institutional Commitment

5. When I first attended collin county community College, I was confident that I'd made the right decision in choosing to attend collin county community College.

6. When I first attended collin county community College, it was very important for me to graduate from collin county Community college.

\section{ACADEMIC INTEGRATION}

Academic Perceptions

1. My out-of-class contacts with instructors have had a positive influence on my intellectual growth.

2. My out-of-class contacts with instructors have had a positive influence on my career goals.

3. My interest in intellectual ideas (or course-related matters) increased during my stay at collin county Community college because of my academic experiences in my classes.

4. Overall, I feel that my academic experiences (grade performance, faculty/counselor contact, positive learning climate, etc.) at collin county community college were very good.

5. Overall, I feel that my career preparation experiences (development of job skills, selection of appropriate career, etc.) at collin county Community college were very good.

Academic Involvement

6. On an average, how often did you participate in class discussion in all your classes during any one semester?

7. During any one semester, how many times did you meet with instructors to discuss class-related issues?

8. How many times did you meet with instructors to discuss class performance? 
Study Behavior

9. On an average, how many hours per week did you spend studying during any one semester?

10. On the average, how many visits to the library did you make per week during any one semester for study/research purposes?

11. On an average, how many counseling/advising sessions did you participate in during any one semester?

VI. SOCIAL INTEGRATION

Social Perceptions

1. The student friendships I have developed at Collin County Community College have been personally satisfying.

2. My relationships with other students have had a positive influence on my personal growth, values, or attitudes. 
COLIIN COUNTY COMMUNITY COLLEGE (CCCC)

DEVELOPMENTAL STUDENT INFORMATION QUESTIONNAIRE

1. Name:

2. Soc. Sec. No.

3. Following is a list of statements characterizing various aspects of academic and social life at Collin County Community College, and with which you may or may not agree. Using the scale to the right of each statement, please indicate the extent of your agreement or disagreement with each statement, as it applies to your Collin Counry Community College experience during the past academic vear, by circling the appropriate number. Please circle ONLY ONE number for each statement.

\section{DURING THE PAST YEAR:}

(1) Few of my mathematics courses this year have been intellectually stimulating

(2) I am satisfied with my developmental mathematics experience at $\begin{array}{lllllll}5 & 4 & 3 & 2 & 1\end{array}$ Collin County Community College this past year

(3) I am more likely to attend a cultural event (for example, a concert, lecture or art show) now than I was a year ago

$\begin{array}{lllll}5 & 4 & 3 & 2 & 1 \\ 5 & 4 & 3 & 2 & 1 \\ & & & & \\ 5 & 4 & 3 & 2 & 1 \\ 5 & 4 & 3 & 2 & 1\end{array}$

(4) I am satisfied with the extent of my intellectual development this year

(5) In addition to required developmental mathematics assignments, $\begin{array}{llllll}5 & 4 & 3 & 2 & 1\end{array}$ I do many of the recommended mathematics assignments in my courses

(6) My interest in ideas and intellectual matters has increased this year.

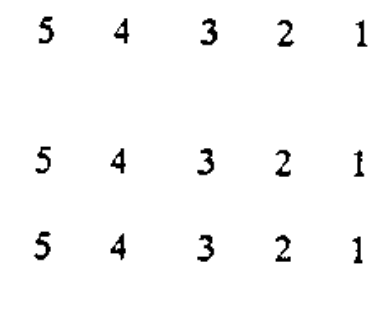

had a positive influence on my intellectual growth

and interest in ideas

(9) Getting good grades in developmental mathematics is not important to me

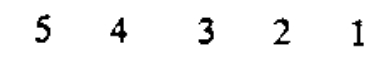

I have performed academically as well as I anticipated I would

My interpersonal relationships with other students have had a positive influence on my intellectual growth and interest in ideas

(12) I have developed close personal relationships with other students

(13) The student friendships I have developed this past year have been personally satisfying

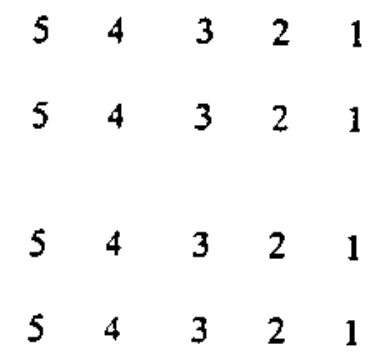


(14) My interpersonal relationships with other students have had a positive influence on my personal growth, values and atrinudes

(15) It has been difficult for me to meet and make friends with other students

(16) I am dissatisfied with my dating relationships

(17) Few of the Collin County Community College students I know $\quad \begin{array}{lllllll}5 & 4 & 3 & 2 & 1\end{array}$ would be willing to isten to me and heip me if I had a personal problem

(18) Most students at Collin County Community College have values and attitudes which are different from my own

(19) I an satisfied with the opportunities to participate in organized extra-curricular activities at Coliin County Community College

(20) I am happy with my housing arrangement this year

(21) I am satisfied with my opportunities this year to meet and interact informaily with factity members

Few of the Collin County Community College faculty memibers I have had contact with this year are willing to spend time outside of class to discuss issues of interest and importance to students

(23) This past year, I have developed a close, personal relationship with at least one developmental mathematics faculty member

(24) My non-classroom interactions with Collin County Community College developmental mathematics faculty members

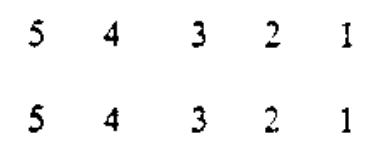

$\begin{array}{lllll}5 & 4 & 3 & 2 & 1\end{array}$ $\begin{array}{lllll}5 & 4 & 3 & 2 & 1\end{array}$ have had a positive influence on my intellectual growth and interest in ideas

(25) My non-ciassroom interactions with developmentai mathematics $\begin{array}{lllllll}5 & 4 & 3 & 2 & 1\end{array}$ faculty this year have had a positive influence on my personal growth. values and attitudes

(26) My non-classroom interactions with developmental mathematics $\begin{array}{llllll}5 & 4 & 3 & 2 & 1\end{array}$ facuity this year have had a positive influence on my career goals and aspirations

(27) Few of the developmental mathematics faculty members I had $\begin{array}{lllllll}5 & 4 & 3 & 2 & 1\end{array}$ contact with this year are genuinely outstanding or superior teachers 
(28) Few of the developmentis mathematics faculty members I have had contact with this year are genuinely interested in students

(29) Most developmental mathematics faculty members I have had contact with this year are genuinely interested in teaching

(30) Most of the Collin County Community College faculty members I have had contact with are interested in helping students grow in more than just academic areas

(31) It is important for me to graduate from college

(32) It is not important to me to graduate from Collin County Community College

(33) I am confident that I made the right decision in choosing to atrend Collin County Community College

(34) It is likely that I will register at Collin County Community College next fafl

$\begin{array}{lllll}5 & 4 & 3 & 2 & 1\end{array}$

$\begin{array}{lllll}5 & 4 & 3 & 2 & 1 \\ 5 & 4 & 3 & 2 & 1 \\ & & & & \\ 5 & 4 & 3 & 2 & 1 \\ 5 & 4 & 3 & 2 & 1 \\ 5 & 4 & 3 & 2 & 1 \\ & & & & \\ 5 & 4 & 3 & 2 & 1\end{array}$

\section{Academic Involvement}

14. During the past year, how frequently have you: (please circle the most appropriate number for each)

\begin{tabular}{l} 
Almost \\
Never Sometimes \\
\hline
\end{tabular}

(36) Expressed your views in developmental mathematics class

Enjoyed your developmental mathematics classes

$\begin{array}{llll}1 & 2 & 3 & 4 \\ 1 & 2 & 3 & 4 \\ 1 & 2 & 3 & 4 \\ 1 & 2 & 3 & 4 \\ 1 & 2 & 3 & 4 \\ 1 & 2 & 3 & 4\end{array}$

(40) Had trouble keeping your mind on what was going on in developmental mathematics class 
Never Sometimes Often Alwavs

(41) Missed a developmental mathematics class

(42) Thought seriously about transferring to another school

(43) Thought seriously about dropping out of school for a while

Done things with a group of other students

(45) Attended campus parties

(46) Felt "at home" here

(47) Met other students who were really interesting

(48) Been able to find interesting things to do on-campus

15. Your gender: Maje(1) Female(2)

16. Your racialethnic background:

White, non-Hispanic (1)

Black, non-Hispanic (2)
Hispanic (3) Amer. Indian/AJaskan Native (4)
AsianPacific Islander (5) Non-resident Alien (6)

Thanks very much for your assistance. Please return the completed questionnaire to your instructor. 
APPENDIX C

CHART 1

116 


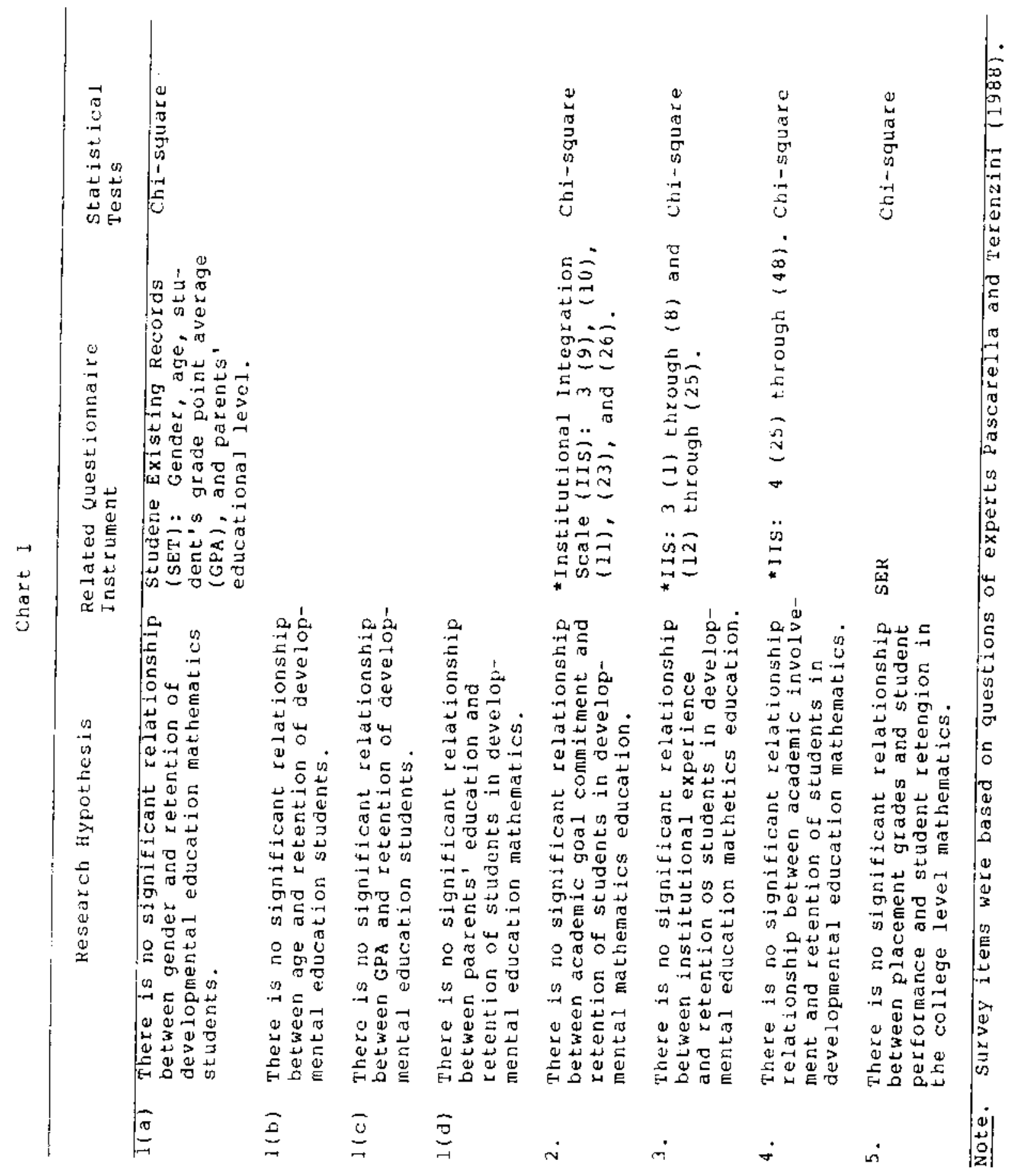

Figure 3. Chart 1: Research hypothesis, related questionnaire instrument, and statistical tests. 
INSTRUMENTS USED TO GATHER DATA

1. Institutional Integration Scale (IIS)

2. Student Existing Records (SER) 
APPENDIX D

CHI-SQUARE CALAULATIONS 
Table 5

Chi-square Calculations for Hypothesis la: Gender vs.

Student Retention

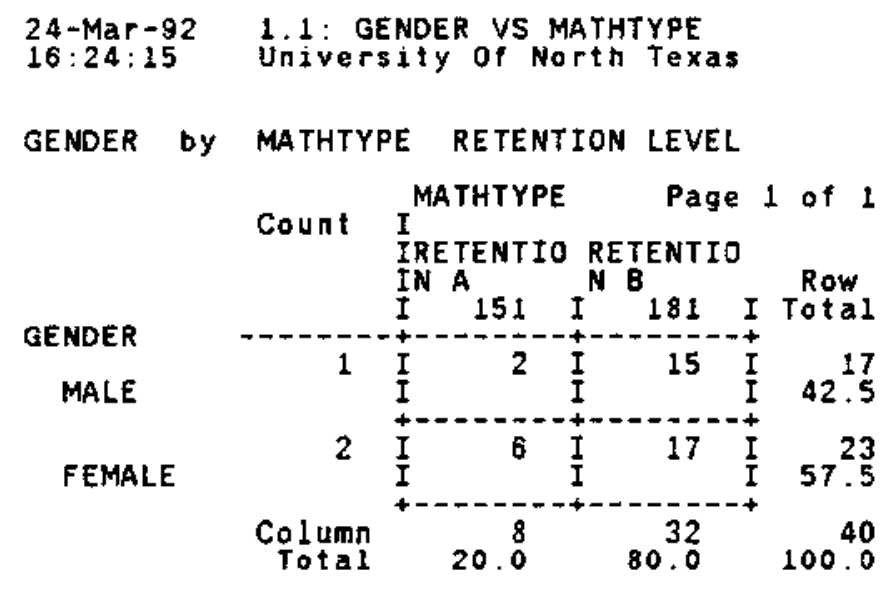

$\mathrm{X}^{2}(1, \underline{\mathrm{N}}=41)=1.25, \mathrm{p} .26$ 
Table 6

Chi-square Calculations for Hypothesis 1b: Age vs. Student Retention

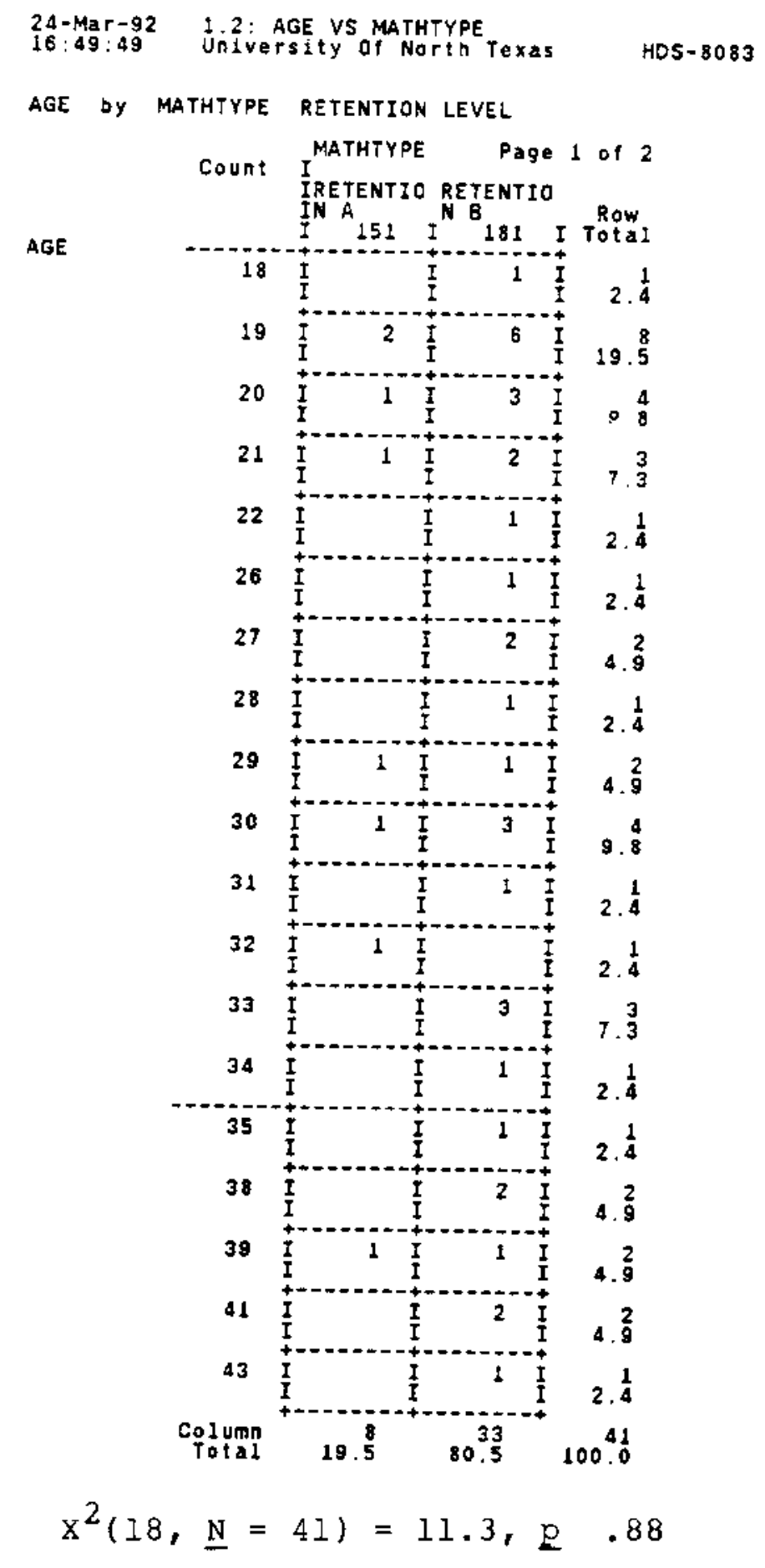


Table 7

Chi-square Calculations for Hypothesis lc: Grade Point Average vs. Student Retention

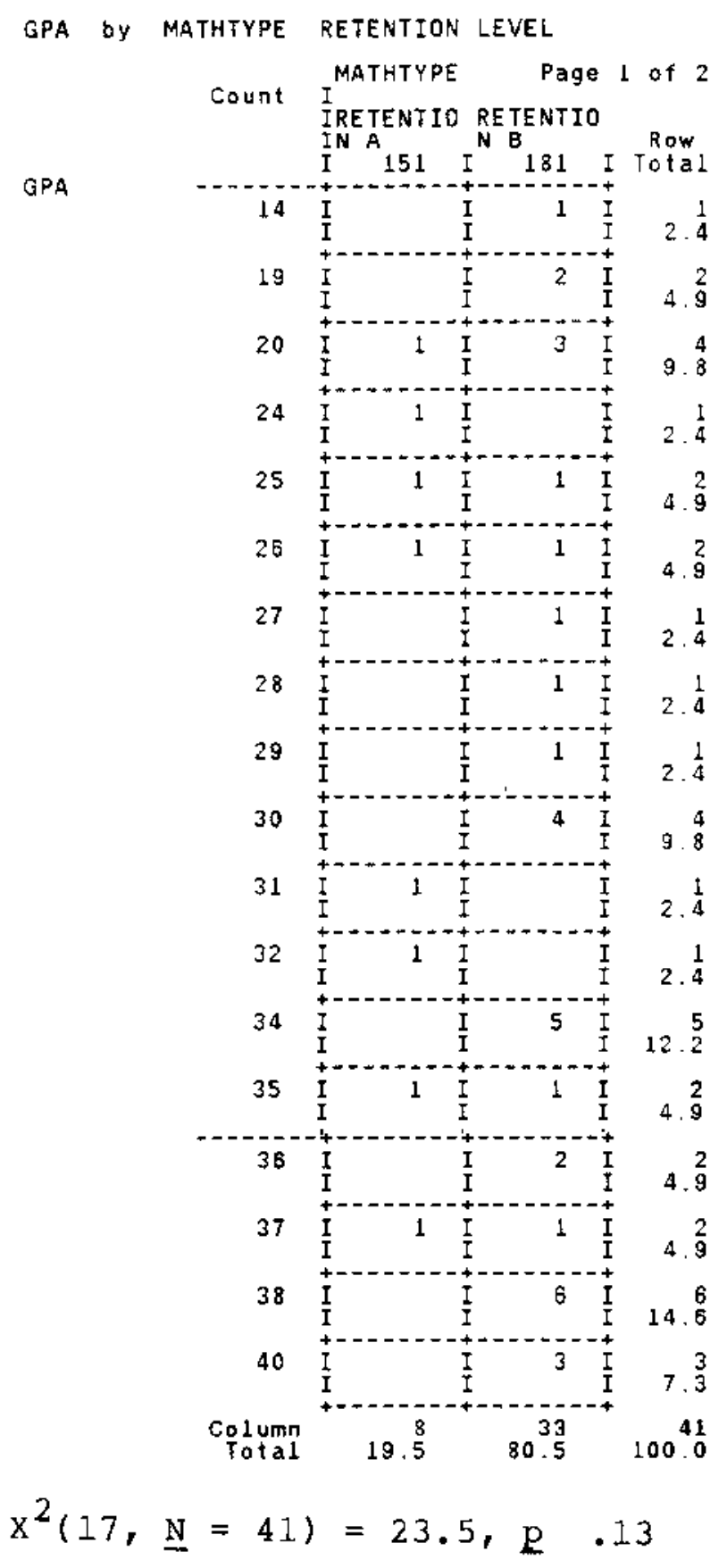


Table 8

Chi-square Calculations for Hypothesis 1d: Parents'

Education vs. Student Retention

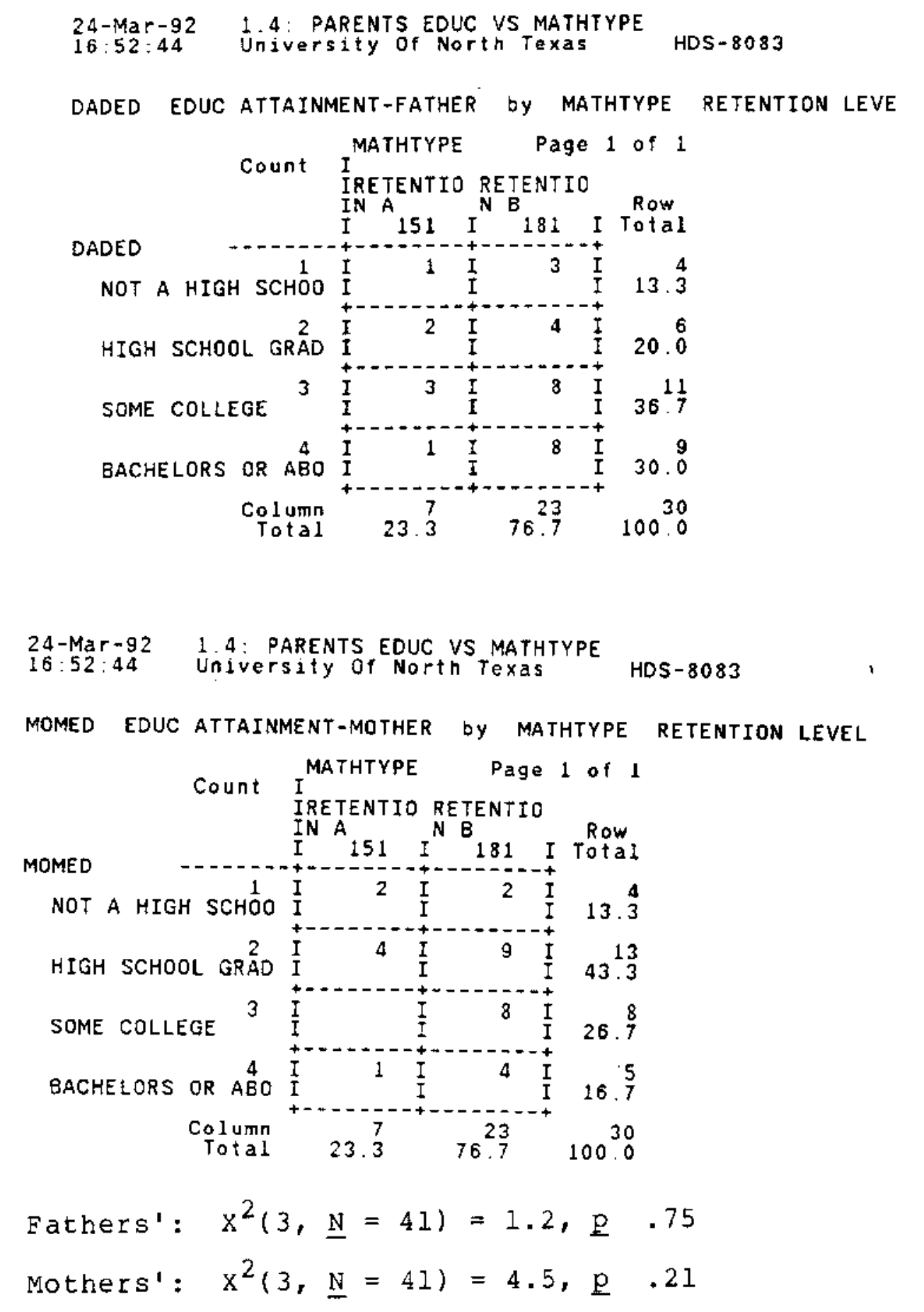


Table 9

Chi-square Calculations for Hypothesis 2: Academic Goal

Achievement vs. Student Retention

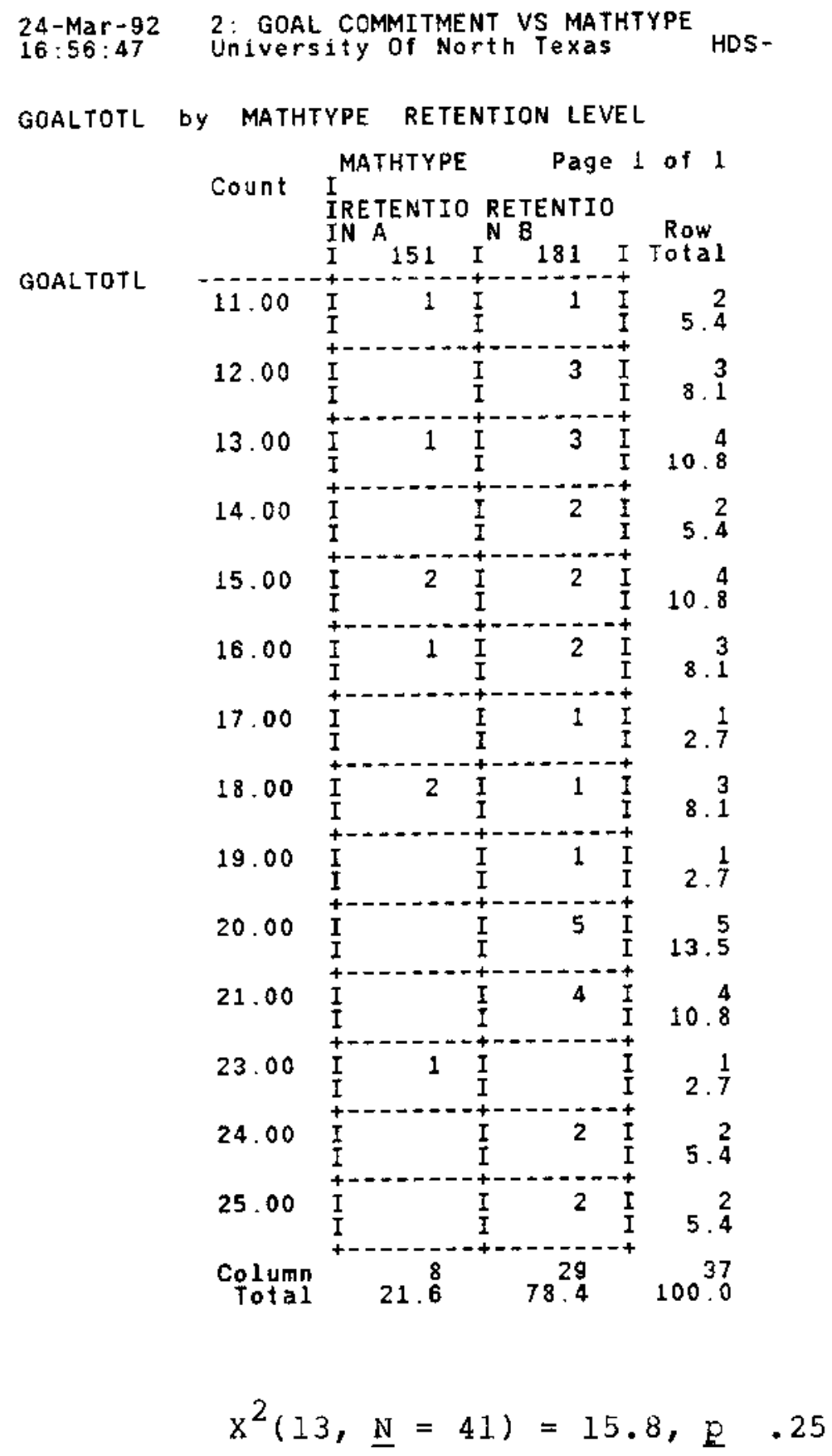


Table 10

Chi-square Calculations for Hypothesis 3: Institutional

Experience vs. Student Retention

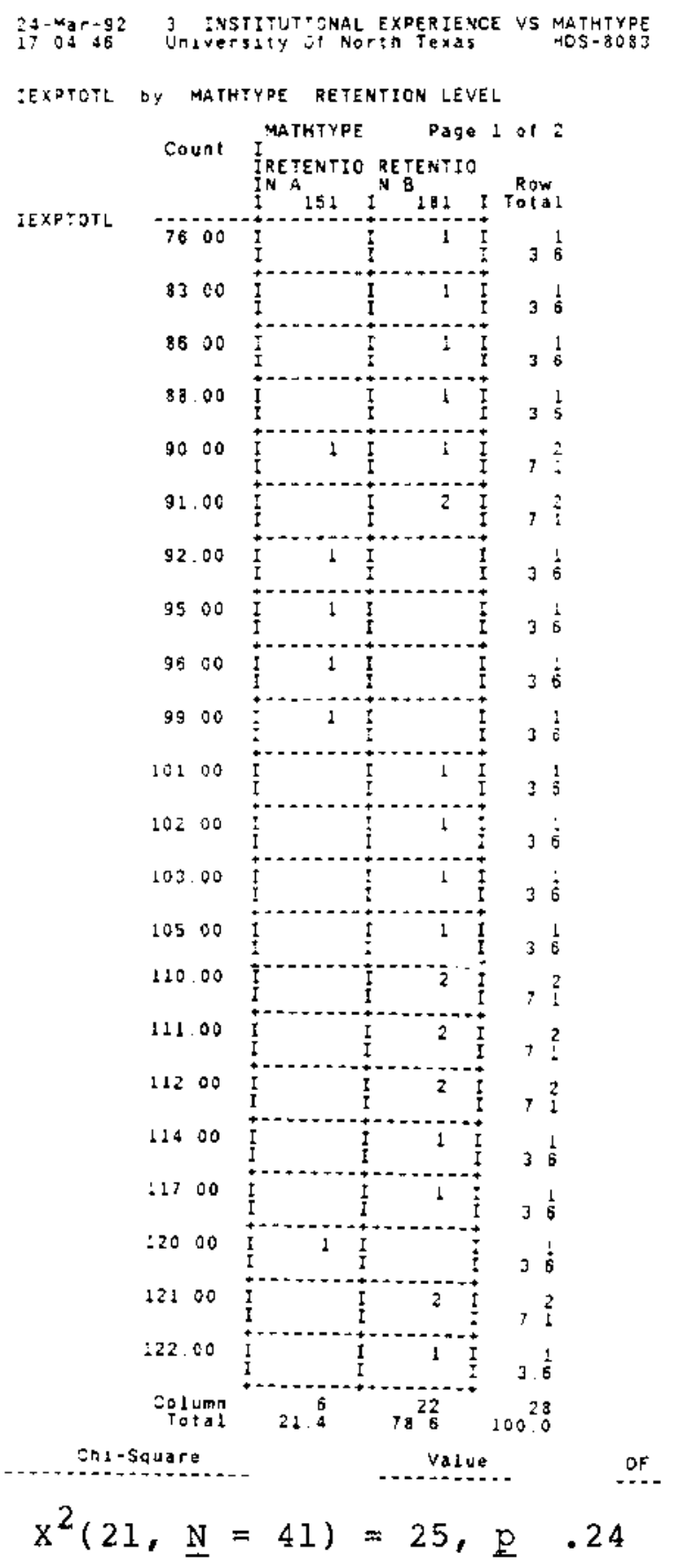


Table 11

Chi-square Calculations for Hypothesis 4: Student Academic Involvement vs. Student Retention

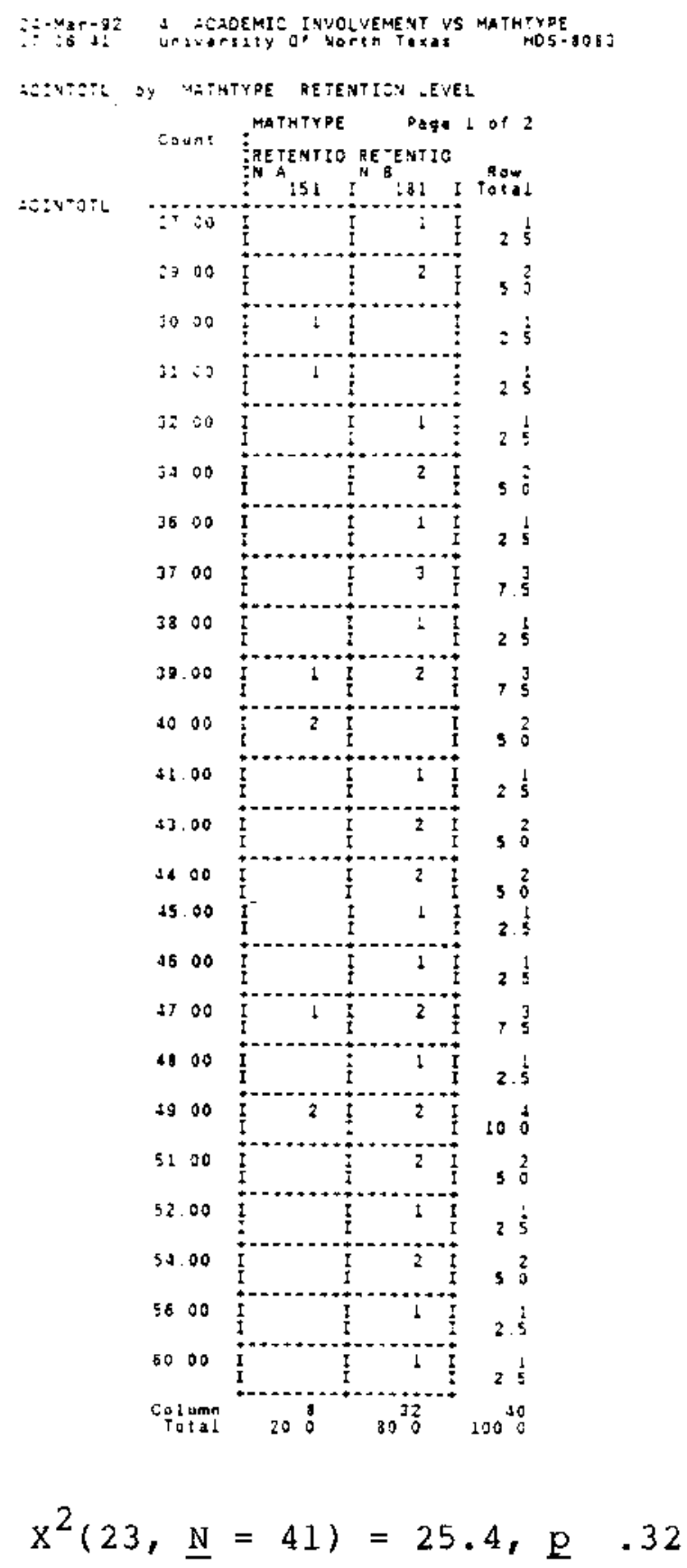


Table 12

Chi-square Calculations for Hypothesis 5: Grades vs.

Student Retention

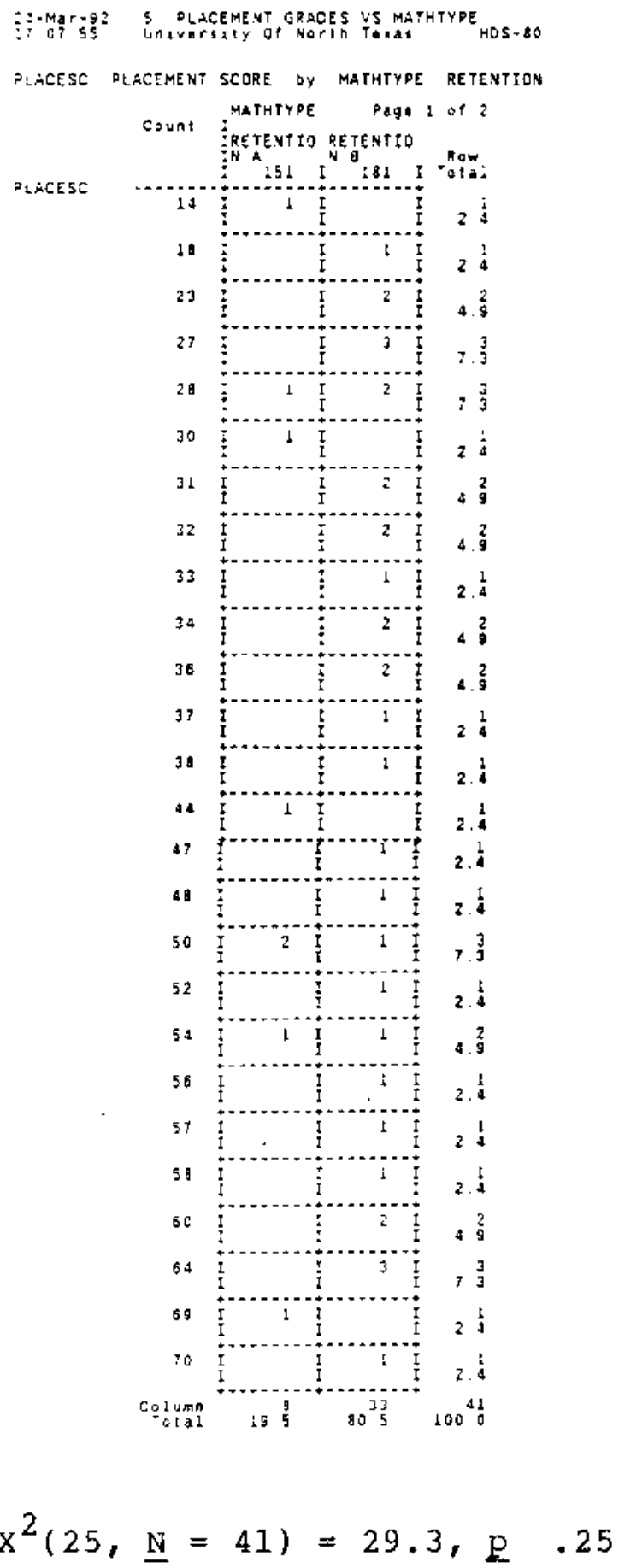


APPENDIX E

Original Institution Intigration Scale (IIS) 
F' 82

so.

$4 / 84$

1. Mane:

For

otive use inly

it -7

2. This dast acadeutic year. dearox indately now many nours oer week. on the averace. did you spend in organized extrd-curricular activities (e.c.. ciubs. ornanizations. athletics) ouring the faLL semester: $h_{r j} . / w k$.:

durine the SPRIJis semester: hrs. $/ \mathrm{mk}$

3. Scudents nave a variety of contacts with faculty menters and ather l'niversity staff nembers \{e.c.. C.V.E. dovisers, residence hall staffi durina an academic yedr.

1) In the first column of blanks below. slease estimate the MuMgER of TlMEs dur ino this past year that you nave met with o faculty memper outside ine tidssraom for each of the reasons lister.

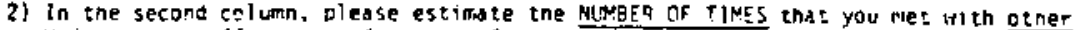
University 5 taf 4 membexs for edch of the same redsotis.

Counc only conversations of 10-15 manutes or mere.

MLMEE ME THES MET HITH : A Faculty anotiner liniv.i

d. To get basic information and device about your acdoennc proaranı.....

b. To olseuss matters related to your future career. . . . . . . . . .

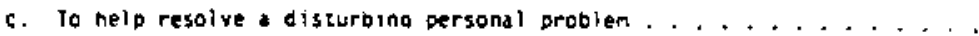

d. To discuss intellectud or course-related matters . . . . . . . .

e. To discuss a canous issue or problem. . . . . . . . . . . . .

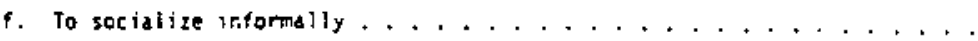

4. Ouring the oast year. has there been ony chanoe in your: (Dledse check I for edch) Memper sidf peroer

\begin{tabular}{|c|c|c|c|c|}
\hline Academic major glans? & $\begin{array}{l}\text { No } \\
\text { Chanae. }\end{array}$ & $\begin{array}{l}\text { Slion: } \\
\text { Cnancter. }\end{array}$ & $\begin{array}{l}\text { Moderste } \\
\text { Shonge. }\end{array}$ & $\begin{array}{l}\text { Great } \\
\text { Change }\end{array}$ \\
\hline Career/vacational platss? & $\begin{array}{l}\text { No } \\
\text { Change, }\end{array}$ & $\begin{array}{l}\text { Sliant } \\
\text { Crange }\end{array}$ & $\begin{array}{l}\text { Moderate } \\
\text { Cnofige }\end{array}$ & $\begin{array}{l}\text { Cired: } \\
\text { Change }\end{array}$ \\
\hline
\end{tabular}

your declared or expected major?

6. What so you expect your career/occubation will be?

7. Students come to colleje witn different odais. some of which are iisted below. Pledse indicate now. important ach goal is for you by circling the dodropriate number next to edch statement.

LITE! CF IMPCRTANEZ

a. To gajn a brodd. liberz: aris education and aboreciation

$t$. To oain knowiedge ore skills direcily doolicabie so a career. . 4 3

$c$. io gain a detailed unoerstandinc of the coricests. issues ant and research methocs ot one or more suguect areas.

-d:--io learn to think cret treily and andyticaij....

. To arepare for future siway, mork and leisure-time activities. . 4 g

§. To learn abour differen: kinos of peoole and to ennance ny inzerpersonal skilis..................... 4 4 I

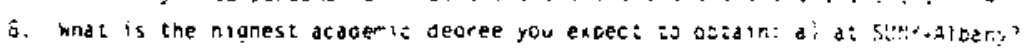

$$
\text { b. onywnere: }
$$

cn k:ork+Stucy" okner an-cancoss

D. Dring the bast year, were you eroloves:

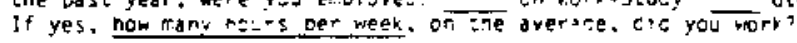

ic. is of the eft of the Fa:" Igs.3semester, what vis vour overall cumidative ordcerpoint averace?

$\therefore$ where cio you live durir.a :ne ods year

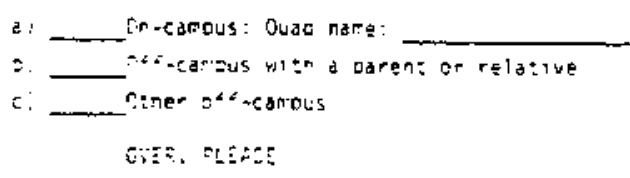


:2. Below are a number of areas that are possible outcomes of attending coilege. Please indicate the prooress you bel ieve you have ande during the past academic year in each of these areas by circling the apgropriate number next to each.

\section{Progress this past year in:} No Prooress
At AII

1. Gaining factual knowledge (terminology, nethods, trends). .

2. Ceveloping the ability to evaluate critically ideas. a terials, and nethods.................

3. Developing the ability to apply abstractions or principles in solving prablens.................

4. Develaping a sense of personal responsfbility fself-reliance

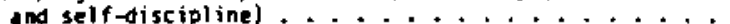

5. Developing skills in expressing myself orally and in writing.

6. Developing an interest in or openness to new toed ......

7. Learning fundamental principles, generalizations, or theories,

8. Developing a elearer idea of my career gods and plans....?

9. Developing a cleurer or better understanding of myself as a person (my interests, talents, values) ......... I

10. Learning how to learn. . ..................

11. Develaping interperson! skills, and the atility to relate to others................. 1

12. Ceveloping the ability to think analytically .........?

13. Developing the abllity to learn on my own.......... 1

34. Developing the atility to formulate creative and oriotol

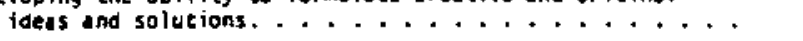

15. Developing oblitty to deal wh comolex morsi and eentcal issues or questions. . . . . . . . . . . . . I

16. Gining exposure to a variety of new intellectual areas. . . I

17. Preparing for graduate or professiomal school study. . . . . I

18. Gaining knowledge and skills directly applicable to a career. I

19. Developing the ability to synthesize * Dody of information. . I

20. Develooing the sbijity to recognize general principles in specific events/conditions ..............

21. Oeveloping intellectual curlosity...............

22. Golining detailed uncerstanding of a particular discipitine's

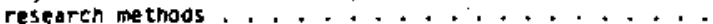

23. Gaining a detailed understanding of particular discipline's various schools of thought ..............

24. Develooing a sense of the inter-relatedness of different disciplines. . . . . . . . . . . . . .

25. Pregaring far active participation in a democratic society..

26. Predaring for continued personal and intellectual growth after college.....................

27. Develaping long-term, leisure-time imasasts ........

28. Preparing for life in a chanoing world . . . . . . . . .

29. Duilding a record of dcademic acnteverent that wit: enmante

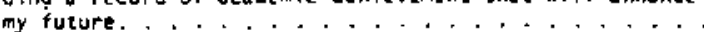

123


13. Following is a list of statements characterizing various aspects of academic and sacial life at Suky-Albany, and with which you way or may not agree. Using the scale to the right of each statement, please indicate the excent of your ogreement or olsagreement with each statement. as it applies to your Albany experience during the past academic year, by circling the appropriate number. Please circle ONL y one number for each statement.

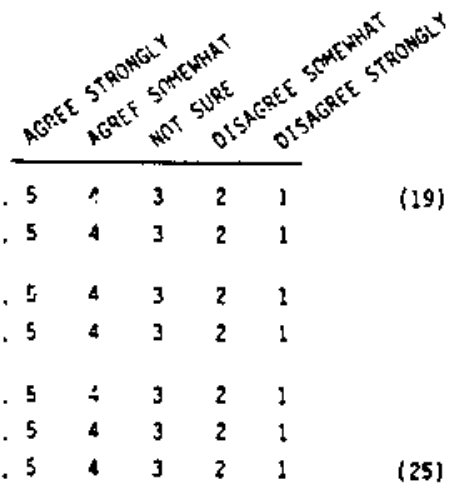

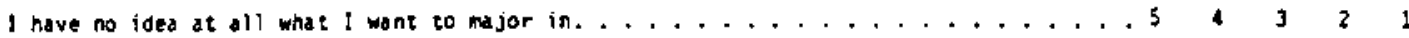

My academic experienct this year has had a positive influence on my intel lectul growth and interest in ideas . . . . . . . . . . . . . . . . . . 5 4 342

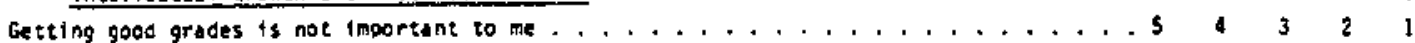

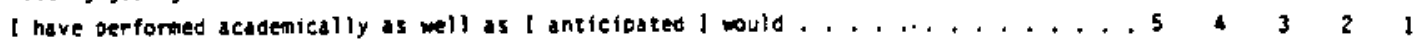

My interpersonal relationshigs whth other students have had positive influence

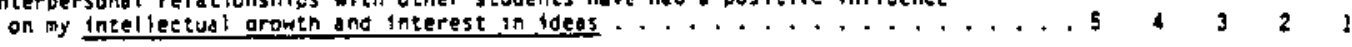

I have developed close personal relotionshios wth other students. . . . . . . . . . . 54432

The student friendships 1 have developed this pasz year have been personally satisfying. . 5 . 32

My incergersonal relationshios with other students have had posteive influence

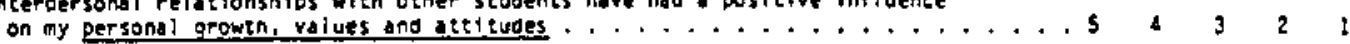

1t has been ofifficult for me to mett and make friends with other students. . . . . . . 5 a 342

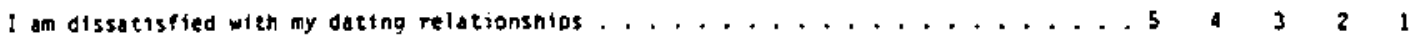

few of the Albany students I know mould be willing to listen to me and help me if I had a personal prablem. . . . . . . . . . . . . . . . . . 5 432

Mose students ot Albany have values and atctidues which are different from my own, . . . 5 . 3 . 1

I am satisfied with the opportuntities to participate in organized extra-curricular

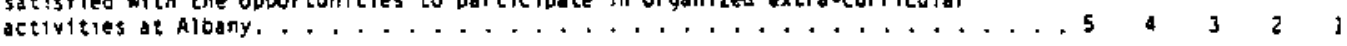

I om haopy wth my living/residence arranaement this year. . . . . . . . . . . . . 5 4 3 . 2

1 din satisfied with my opoortunities this year to meet and interact

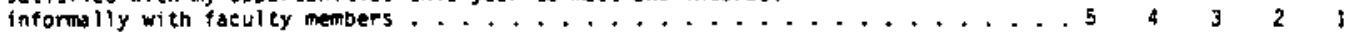

Few of the Albany faculty members I have had contact with this year are will fno to soend time outside of class to discuss issues of interest and incortance

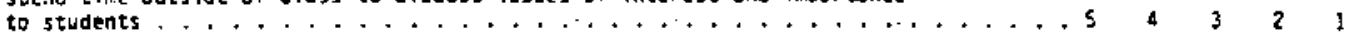

This past year, I have develooed close, personal relationship with at least one factulty meroer . . . . . . . . . . . . . . . . . . . . . . . . . 5 4332

My non-clossroom interactions with Rloany faculty members have had a positive influence on my intellectual arowth and interest in ideas . . . . . . . . . . . . . 5 43 31

My nan-classroom interactions with faculty enss year hove had a positive

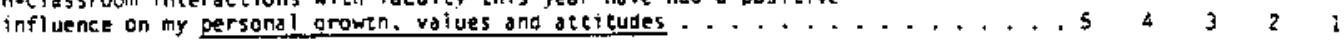

My non-classmoom inceractions with faculty this year hove thad a positive influence on my career goals and ascirations. . . . . . . . . . . . . . . . . . . . . 5 $4 \quad 3 \quad 2 \quad 1$

Few of the faculty members I had concact with this yedr are genuinely outstanding or superior teachers. . . . . . . . . . . . . . . . . . . . . . . . . $54{ }^{4} 2$

Few of the faculty members I have nad contact with this year are genuinely interested in students. . . . . . . . . . . . . . . . . . . . . . . . 5 431

Most faculty menbers I have had contact with this year ore genulneiy incereszed in teachins. 


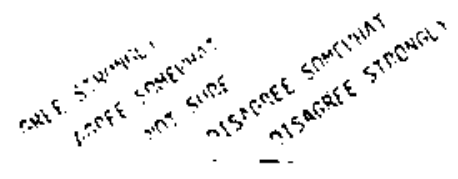

Host of the Albany faculty mewoers I have hau asm...t mith ore interested in

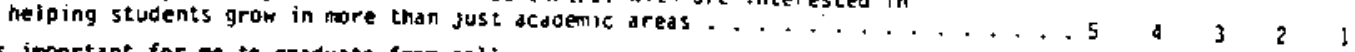

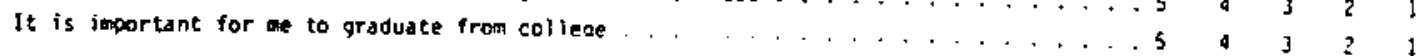

It is not importane to me to graduale from sunt-Aloany . . . . . . . . . . . . . . . . 5 A J 2 ,

I an confident that $I$ made the right decision in choosinọ to attend Albany. . . . . . . 5 . 3 . 2

It is likely that 1 will register at Albany next fail . . . . . . . . . . . . . . . 5 4 342

14. During the past year, how frequently have you: (olease circle the most approoriace number for each)

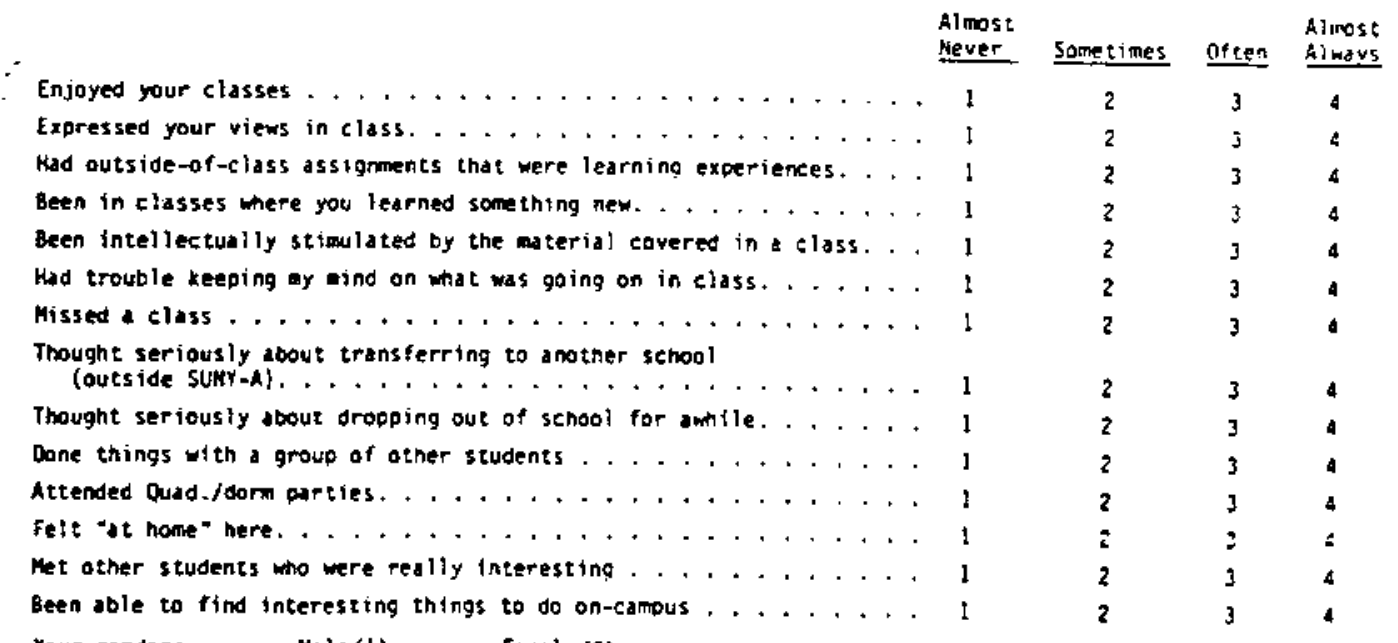

15. Your gender : Male (1) Female (2)

16. Your ractal/ethntc background: White, non-Hispanic (1)

Mispanis (3)

Asian/Pacific Islander (5) B]ack, mon-Hispanic (2)

Aner. Indian/Alaskan Native (4)

Hon-resident silien

EEHERAL EDUCATION PROGRAM

17. Many people believe that all undergradustes, as a fundamental part of their education, should be exposed to certain, broad areas of knowledge. Do you share that belief? (Please eheck one.)

1. Not at all 2 . To d slight extent 3 . To moderate extent

4. To a large extent

18. Please review the definitions (enclosed with this ouestionnaire) of the six areas that oefine Suny-Altany's General Education Program. Then, 1 lolease write in the number of General Ecucation courses you have taken (or are taking) in each semester this year. and 2 ) indicate by circling the aporopria the courses vou have taxen corresoond--on the dverage-to the descriocions.

No. of tenen. Ed.

General Eduction Courses Taken Correspontence to Caleoory Descriocion

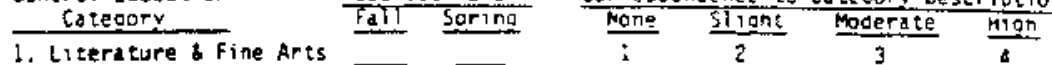

2. Natural Scrence -5 -

3. Social science

4. Symbolics

5. values

6. Warld eultures

$$
\text { 三 }
$$

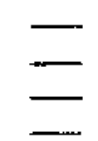

1

12

12

12

I 2

19. By what semester and year to you expect to have satsfied all General Education reouirements fincluoung the writing intensive reauirement?

$$
\text { Aear: }
$$

Semester

TिI/SOrIm:

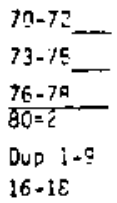


REFERENCES

Achora, C., \& McCary, P. (1974). The impact of attrition on the self-concept and anxiety level of freshmen nursing students at the University of Northern Colorado. Colorado Journal of Educational Research, 13, 36-42.

Aitken, N. D. (1982). College student performance, satisfaction \& retention. Journal of Higher Education, $53,32-50$.

Astin, A. W. (1964). Personal and environmental factors associated with college aropouts among high aptitude students. Journal of Educational Psychology, 6므, 219-227.

Astin, A.W. (1972, February). College dropouts: A national profile. (Report No. $\mathrm{HE}-002-861$ ). Washington, DC. (ERIC Document Reproduction service No. 059691 , Vol. 7, No. I)

Astin, A.W. (1973). Student persistence: Some stay, some don't--why? College and University, 4으, 298-306.

Astin, A. W. (1975). Preventing students from dropping out. San Francisco: Jossey-Bass.

Astin, A. W. (1978). Four critical years. San Francisco: Jossey-Bass.

Astin, A. W., \& Panos, R. J. (1969). The educational and vocational development of college students. Washington, DC: American council on Education.

Astin, A. W., Korn, W., \&Green, K. (1987). Irends and data: Retaining aná satisfying students. Educational Record, $68,36-42$.

Attinasi, L. C. (1986). Getting in: Mexican American students' perceptions of their college behavior with implications for their freshman year persistence in the university. Unpublished Doctoral Dissertation, Arizona state University.

Bayer, A. E. (1968). The college dropout: Factors affecting senior college completion. Sociology of Education, $41,305-316$. 
Beal, P. E., \& Noel, L. (1980). What works in stuoent retention. Iowa City: American College Testing Program and $\mathrm{Nat}$ ional Center for Higher Education Management systems.

Bean, J. P. (1980). Dropouts and turnover: The synthesis and test of a causal model of student attrition. Research in Higher Education, 12, 155-187.

Bean, J. P. (1981). Student attrition, intentions, and confidence: Interaction effects in a path model. Paper presented at the annual meeting or the American Educational Research Association, Los Angeles.

Bean, J. P. (1982). Student attrition, intentions, and confidence: Interaction effects in a path model. Research in Higher Education, 17 , 291-320.

Bean, J. P. (1985). Interaction effects based on class level in an explanatory model of college student dropout syndrome. American Educational Research, 22(L), 35-64.

Bean, J. P., \& Metzner, B. S. (1985). A conceptual model of nontraditional undergraduate student attrition. Review of Educational Research, 55, 485-540.

Bean, J. P., \& Metzner, B. S. (1987). The estimation of a conceptual model of nontraditional undergraduate students attrition. Research in Higher Education, 27(1), 15-38.

Beckwith, M. M. (1980). Science education in two-year colleges: Mathematics. T(Report No. JC $80 \overline{0} \overline{3} \overline{0}$ ). Los Angeles: Center for the stuoy of Community colleges and ERIC Clearinghouse for Junior Colleges. (ERIC Document Reproduction Service Report No. 187 386)

Biddle, B. J., \& Thomas, E. J. (1966). Role theory. New York: Wiley.

Blanchfield, W. C. (1971). College dropout identification: A case study. Journal of Experimental Education, $\underline{40}, 1-4$.

Brag, E. W. (1956). A study of student withdrawal at "W.

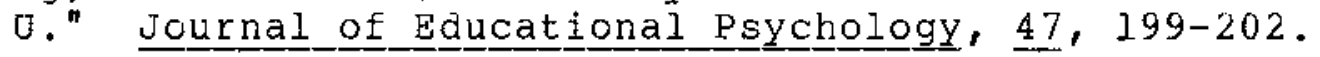

Brunson, P. W. (1983). A classroom experiment involving basic mathematics and women. Two-year College Mathematics Journal, $1 \underline{4}(4), 38 \overline{1}-4 \overline{2} \bar{l}$.

Catalano, J. T. (1985). Keeping college students in colleges: A motivation-retention model. Colleges staudent Jouㅡ므믄, 19, 255-260. 
Change, P. T. (1983, April 15-16). College developmenta1 mathematics-national survey. Paper presented at the Annual Convention of the Mathematical Association of America, Charleston, SC.

Chickering, A. W. \& Hannah, W. (1969). Process of withdrawal. Liberal Education, 55, 551-558.

Conner, J. D. (1968). The relationship between college environmental press and freshman attrition at Southern Methodist university. College and University, 43 , $265-273$.

Cope, R. G. (1980). What works in student retention? (Report of a joint project by $\overline{\mathrm{P}}$. C. $\overline{\mathrm{B} e \bar{l}}$, $\overline{\mathrm{s}} \mathrm{L}$ Noel). Iowa City and Boulder: American College Testing Program and National Center for Higher Education Management systems.

Cope, R. C., \& Hannah, W. (1975). Revolving college doors: The causes and consequences of dropping out, stopping out, and transferring. New York: Wiley and Sons.

Crepin, D. M. (1981). A developmental mathematics program for community college students. (Report No. JC 810 659). Unpublished paper, Lower columbia College, Washington. (ERIC Document Reproauction service No. ED $210076)$

Cross, K. P. (1971). Beyond the open door: New students to higher education. San Francisco: Jossey-Bass.

Cross, K. P. (1976). Accent on learning: Improving. instruction and reshaping the curriculum. San Francisco: Jossey-Bass.

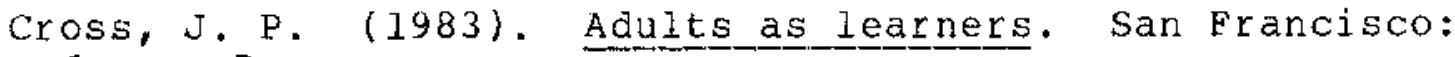
Jossey-Bass.

Deegan, W. L., Tillery, D, \& Associates. (1985). Renewing_ the American Community College. San Francisco: Jossey-Bass.

Dressel, P. L., \& Simpson, W. A. (1980). Student persistence and benefits: Program selection and äegree completion. (Report No. HE 015 285). (ERIC Document Reproduction Service No. ED 219 996)

Durkheim, E. (1961). Suicide (J. Spaulding \& G. Simpson, Trans.). Glencoe, IL: The Free Press. 
Dyer, P. A. (1981). American mathematical association for two-year colleges developmental mathematics curriculum committee annual report. (Report No. JC $8 \overline{1} 0625$ ). Unpublished paper. (ERIC Document Reproduction Service No. ED 208 924)

Eckland, B. K. (1964). College dropouts who came back! Harvard Educational Review, $24,402-420$.

Eckland, B. K. (1964a). Social class and college graduation: Some misconceptions corrected. American Journal of sociology, $70,36-50$.

Eckland, B. K. (1964b). A source of error in college attrition studies. Sociology of Education, 38, 60-72.

Eckland, B. K. (1965). Acaojemic ability, higher education, and occupational mobility. American Sociological Review, 30, 735-746.

Eddy, John, Cockran, Judith, \& Haney, Charles. (1980). College student retention studies and strategies. In John Eddy, Joseph D. Dameron, and David 'I'. Borland (Eds.), College student personnel, development, administration, and counseling, (2nd ed., p. $\left.\frac{46}{1}\right)$. New York: University Press of America.

El-Khawas, E. (1986a). Community colleges reconsider curricula. Education Record, 67, 46-49.

El-Khawas, E. (1986b). Campus trends 1986. (Higher Education panel Report No. 73). Washington DC: American Council on Education.

Fishbein, M., \& Ajzen, I. (1975). Belief, attitude, intention and behavior: An introduction to theory ä research. Reading, MA: Adōison-Wesley.

Fox, J. (1985). Application of a conceptual model of college withdrawa to disadvantaged students. Paper presented at the annual meeting of American Educational Research Association, Chicago, IL.

Friedlander, J. (1981, April 13-17). Student participation and success in comunity college science eaucation program. Paper presented at the Annual Meeting of the American Educational Research Association, Los Angeles. (ERIC Document Reproduction Service No. ED 201 374)

Fullmer, D. W. (1956). Success and perseverence of university students. Journal of Higher_Education, 27, $445-447$. 
Golaberg, D. (1983). Integrating writing into the mathematics curriculum. I'wo-Year College Mathematics Journal, 1 生 (5), 421-424.

Gosman, E. J., Betty, A. D., Michael, T. N., \& Thoeny, A. R. (1983). Predicting student progression: The influence of race and other student and institutional characteristics on college student performance. Research in Higher Equcation, 18(2), 209-237.

Gross, F. L., Jr. (1981). Teaching the whole mind: A developmental-structural approach. Journal of General Education, 33(3), $175-188$

Hackman, J. R, \& Dysinger, W. S. (1970). Commitment to college as a factor in student attrition. Sociology of Education, 43, 311-324.

Halpin, R. L. (1990). An application of the Tinto model to the analysis of freshman persistence in a community college. Community College Review, 17(4), 22-31.

Hayes, E. (1981). Prediction cf academic success in a baccalaureate nursing educaticin program. Journal of Nursing Education, 20, 4-8.

Hecklinger, Fred J. (1972) The undecided student: Is he less satisfied with college? Journal of College student Personnel, 13, 247-251.

Hegarty, W. H. (1975). Organizational and sociological factors affecting attrition ir collegiate schools of nursing. International Journal of Nursing Studies, 12 (4), 217=222 .

Hughes, R. (1983). The non-traditional student in higher education: A synthesis of the literature. NASPA Journal. $\underline{20}, 51-64$.

Iffert, R. E. (1957). Retention and withdrawal of college students (Bulletin 58, No. I). U. S. Department of $\overline{\mathrm{H}} \overline{\mathrm{e}} \overline{\mathrm{t}} \mathrm{h}, \mathrm{Education}$, and Welfare. Washington: U. S. Government Printing office.

Kamens, D. H. (1971). The college "charter" and college size: Effects on occupational choice and college attrition. Sociology of Education, 44, 270-296.

Kasworm, C. E. (1980). The older student as an undergraduate. Aadult Education, 31, 30-47. 
Kohen, A. I., Nestel, G., \& Karmas, C. (1978). Factors affecting individual persistence rates in undergraduate college programs. American Educational Research Journal, $15,233-252$.

Krathwohl, D. R. (EÖ). (1969). Taxonomy of educational objectives: Affective domain. N New York: Mackay.

Laman, M. A. (1989). The influence of selected factors on nonpersistence of nontraditional students a comprehensive community college. unpublished doctoral assertation, university of North Texas, Denton.

Lea, H. D., Sedlacek, W. E., \& Stewart, S. S. (1979). Problems in retention research in higher education. Research in Higher Education, 16 , 2-8.

Lenning, O. T. (1982). Variable-selection and measurement concerns. In E. T. Pascarella (Ed.), New directions for institutional research, II (pp. 35-44). San Francisco: Jossey-Bass.

Lenning, O. T., Beal, P. E., \& Sauer, K. (1980). Retention and attrition: Evidence for action and research. Boulder, CO: National Center for Higher Eđucation Management systems.

Little, J. K. (1959). The persistence of academically talented youth in university studies. Educational Recorä, $40,237-241$.

Lum, G. \& Alfied, R. L. (1987). Remedial program policies, student demographic characteristics and performance outcomes in commurity colleges. (Report No. HE $0203 \overline{5} 6$ ) $\bar{A} \cdot \bar{S} \cdot \bar{H} \cdot \bar{E}$. paper presented at annual meeting. (ERIC Document Reproduction Service No. ED $281-452$ )

MacMillan, T. F., \& Kester, D. M. (1973). Promises to keep: NORCAL impact on student attrition. Community and Junior College Journal, $4 \underline{3}, 45-46$.

Malin, Jane $\mathrm{T}$, , Bray, James $\mathrm{H}$. , Dougherty, Thomas $\mathrm{W}$. , \& Skinner, Ken W. (1980). Factors affecting the performance and satisfaction of adult men and women attending college. Research in Higher Education, 13. $115-130$.

Marks, E. (1967). Student perceptions of college persistence and their intellective, personality and performance correlates. Journal of Educational Psychology, 58, 221-221. 
Maslow, A. H. (1987). Motivation and personality. New York: Harper.

MCNeely, J. J. (1937). College student mortality. Bulletin No. 11. Washington, DC: U. S. Office of Education.

Miller, B. W., \& Rode, J. (1983). A case study in recruiting, marketing, and retention from the university to the community college. In Bob $W$. Miller \& John P. Eddy (Eds.), Recruiting, marketing and retention in institutions of higher education (pp. 100-106). New York: University press of America.

Miller, M. R. (1978). New educational designs for a new clientele. In L. Noel (Ed.) Reducing the aropout rate (pp. 47-56). San Francisco: Jossey-Bass.

Morrisey, R. J. (1971). Attrition in probationary freshmen. Journal of College Student Personnel, 12 (4), $279-285$.

Nelson, R. B., Scott, T. B., \& Bryan, W. A. (1984). Precollege characteristics and early college experiences as predictors of freshman year persistance. Journal College

Nora, A. (1987). Determinants of retention among Chicano college students: A structural model. Research in Higher Education, 26 6 (1), 31-59.

Olivas, M. A. (1979). The dilemma of access. Washington DC: Harvard University.

Panos, R. J., \& Astin, A. W. (1968). Attrition among college students. ACE Research Reports, $2(\overline{4})$.

Pantages, T. I. \& Creedon, C. F. (1978). Studies of college attrition: 1950-1975. Review of Educational. Research, $\underline{4}$ 8 (49-101).

Pappas, J. P., \& Loring, R. K. (1985). Returning students. In L. Noel and R. Levitz (Eds.), Reducing the dropopout_rate. San Francisco: Jossey-Bass.

Pascarella, E. T. (1980). Stuclent-faculty informal contact and college outcomes. Review of Educational Research, 50, 545-595.

Pascarella, E. T. (1982). Sttudy San Francisco: Jossey-Bass. 
Pascarella, E. T. (1986). A program for research and policy development on student persistence at the institutional level. Journal of College student Personnel, 27, 100-107.

Pascarella, E. I'., \& Chapman, D. W. (1983). A multi-institutional, path analytic validation of Iinto's model of college withärawal. American Educational Research Journal, $2 \underline{0}(1), 87-10 \overline{2}$.

Pascarella, E. T., Duby, P. B., Terenzini, P. T., \& Iverson, B. K. (1983). Student-faculty relationship and freshman year intellectual and personal growth in a nonresiojential setting. Journal of College stugent Personnel, 24, 395-402.

Pascarella, E. T., Smart, J. C., \& Ethington, , C. A. (1986). Long-term persistence of two-year college students. Research in Higher Education, 24, 47-71.

Pascarella, E. T., \& Terenzini, P. T. (1983). Predicting voluntary Ereshman year persistence/withdrawal behavior in a residential university: A path analytic validation of Tinto's model. Journal of Educational Psychology, $7 \underline{5}$, $215-226$.

Pascarelia, E. T., \& Wolfe, L. M. (1985). Persistence in higher education: A nine-year test of a theoretical model. Paper presented at the annual meeting of the American Educational Research Association, Chicago, IL.

Pedrini, B, \& Pedrini, D. T. (1977). Multivariate prediction of attrition/persistence for disadvantaged and control collegians. College Student Journal, 11, 239-242.

Peterson, G. I.. (1978). West Valley College comprehensive plan for special education. Saratoga, CA: West Valley College.

Planning your education: A guide to getting the most out of high school. (1982). Miami: Eurdines Department Stores. (ERIC Document Reproduction service No. ED 231410 )

Prediger, D. J. (1965). Prediction of persistence in college. Journal of Counseling Psychology, $12,62-67$.

Rendon, L. I. (1982). Chicanos: in South Texas community colleges: A study of student and institutional-related determinants of educational ottcomes. Unpublished doctoral dissertation, University of Michigan.

Rever, P. R., \& Kojaku, L. K. (1976). Access, attrition, test scores, and grades of college entrants and 
persisters: 1965-1973. Research in Higher Education, 5 , 289-299.

Riley, M. (1984). The community college general academic assessment: Los Angeles district (unpublished report). Los Angeles: Center for the Study of Community colleges.

Roelf, Pamela. (1974). Effects of changing ages and sex composition of college student bodies. (ERIC Document ED 097088, Chicago)

Rotman, J. W. (1972). Voluntary withdrawal from a total adult socializing organization: A model. Sociology of Education, 45, 258-270.

Roscoe, J. T. (1975). Fundamental research statistics for the behavioral sciences (2nd ed.). New York: Holt Rinehart and Winston.

Rouche, J. E., \& Snow, J. J. (1977). Overcoming learning problems. San Francisco: Josey-Bass.

Roueche, J. E., Baker, G., \& Roueche, S. D. (1984). College response to low achievement students. Orlando, FL: HBJ Mediation stystem corporation.

Seale, R. (1984). A structural model for explaining retention and attrition in a comunity college. Unpublished Doctoral Dissertation, University of Houston.

Sewel, W., \& Shah, V. P. (1967). Socioeconomic status, intelligence and the attainment of higher education. Sociology of Education, 40, 1-23.

Sewel, w., \& Shah, V. P. (1968). Social class, parental encouragement, and educational aspirations. American Journa 1 of Sociology, LXXIII, 559-572.

Sexton, V. (1965). Factors contributing to attrition in college populations: Twenty-five years of research. Journal of General Psychology, 73, 301-326.

Slater, M. (1957). Perception: A context for the consideration of persistence and attrition among college men. Personnel and Guidance Journal, 35, 435-440.

Slocum, W. L. (1956). Social factors involved in academic mortality. College and University, 32, 53-64.

Smart, J. C., \& Pascarella, E. T. (1987). Influences on the intention to reenter higher education. Journal of Higher Equcation, 58, 306-322. 
Spady, w. G. (1970). Dropouts from higher education: An interdisciplinary review and synthesis. Interchange, 1 , $64-85$.

Spady, W. G. (1971). Dropouts from higher education: Toward an empirical model. Interchange, $\underline{2}$ 38-62.

Starr, A., Betz, E, \& Menne, J. (1972). Differences in college students' satisfaction: Academic dropouts, non-academic dropouts, and non-dropouts. Journal of Counseling Psychology, 19, 318-322.

Strowbridge, E. D. (1987). Tleaching the developmental education student new directions for community colleges. San Francisco: Jossey-Bass.

Summerskill, J. (1962). Dropouts from college. In s. Sanford (Ed.) The American college (pp. 627-657). New York: John Wiley and Sons.

Timmons, F. (1972). Personality and demographic factors associated with freshman withdrawal from college (Doctoral dissertation, University of Colorado.) Dissertation Abstracts. Internation, 33 (4-B), 1808-1809.

Tinto, V. (1975). Dropout from higher education: A theoretical synthesis of recent research. Review of Educational Research, 4느, 89-125.

Tinto, V. (1987). Leaving college: Rethinking the causes and cure of studentattrition. Chicago: The University of chicago press.

Trent, J. W., \& Medsker, L. L. (1968). Beyond high School. San Francisco: Jossey-Bass.

Vaughan, G. B. (Ed.). (1980). Questioning the community. college role. San Francisco: Jossey-Bass.

Voorhees, R. A. (1987). Toward building models of community college persistence: A logit analysis. Resea

Webb, M. W. (1988). Freshman year retention at three campuses of a large urban community college district 1983-1986. Community Junior College Quarterly, 12, $213-242$.

Willett, L. H. (1983). One-stop or stop-out? A five-year longitudinal analysis of community college attendance. Community/Junior College Quarterly, 7, 59-64. 
wood, J. P. (1980). Mathematics placement testing. In F. B. Brawer (Ed.). New directions for community colleges: Teaching the sciences. San Francisco: Jossey-Bass.

Zwerling, L. S. (1980). The "new" new student: The working adult. In G. B. Vaughan (Ed.), Questioning the community college role (pp. 93-100). San Francisco: Jossey-Bass. 